\title{
TRUE INTEGRATION: ADVANCING BROWN'S GOAL OF EDUCATIONAL EQUITY IN THE WAKE OF GRUTTER
}

\author{
Lia B. Epperson*
}

\section{INTRODUCTION}

The late Supreme Court Justice Thurgood Marshall, founder of the NAACP Legal Defense Fund ("LDF"), and head of the legal team that litigated Brown v. Board of Education, ${ }^{1}$ knew well the challenges that desegregation posed in a nation founded on a system of racial subjugation and white supremacy. A full thirty years after Brown, he acknowledged:

Desegregation is not and was never expected to be an easy task. Racial attitudes ingrained in our Nation's childhood and adolescence are not quickly thrown aside in its middle years. . . . In the short run, it may seem to be the easier course to allow our great metropolitan areas to be divided up each into two cities — one white, the other black — but it is a course, I predict, our people will ultimately regret. ${ }^{2}$

Although Brown's role in ending state-mandated racial segregation in public schools is well-known throughout this country, the story did not end with the Supreme Court decision in 1954, nor did it end with Brown's companion case one year later. ${ }^{3}$ In truth, the promise of Brown, so revolutionary at its inception, was frustrated at key intervals by a number of actors. Perhaps the most significant of these was the very institution that gave it life-the Supreme Court. As a result, although we have traveled fifty years from that momentous ruling, we, as a nation, have had less than half that time to actively work to achieve its covenant and ensure full equality of educational opportunities.

\footnotetext{
* Assistant Professor of Law, Santa Clara University School of Law, former Director of Education, NAACP Legal Defense and Educational Fund, Inc. I owe thanks to Michelle Adams, Richard Ford, Benjamin Jealous, and Muriel Morisey for their generous and helpful comments on previous drafts of this article.

1. 347 U.S. 483 (1954).

2. Milliken v. Bradley, 418 U.S. 717, 814-15 (1974) (Marshall, J., dissenting).

3. See Brown v. Bd. of Educ., 349 U.S. 294, 301 (1955) (announcing that school districts must desegregate "with all deliberate speed") [hereinafter Brown II].
} 
After a rather slow start, the Supreme Court issued a series of critical opinions that gave meaning to desegregation in education in the first two decades after Brown. Yet in the mid- to late-1970s, the Court issued opinions that curtailed the financial equalization of schools and rejected metropolitan desegregation. These decisions signaled a shift away from integrative remedies and altered the nature of desegregation orders. The Court made it extremely difficult for districts to achieve equality through integration, and instead limited the options to seeking adequacy through remedial funding of segregated schools.

Although federal court-ordered desegregation plans continued in the South, by the 1990s a conservative Court led by Chief Justice Rehnquist essentially relinquished its obligation to require school districts to remedy racial segregation. The Rehnquist Court issued a trilogy of opinions that severely limited the circumstances, means and duration of desegregation, remedies; stated its desire to end federal court supervision; and invoked the common mantra of restoring control to local school systems. ${ }^{4}$ The lie behind this glorification of local control is similar to the Court's embrace of "color blindness" in many other contexts. It is a standard that treats whites and blacks as if they were similarly situated and ignores the history of segregation and its vestiges that have been such unique and intrinsic threads in the American tapestry. This form of local control allowed segregation to flourish in the era before Brown, and has done so again in the decade since these decisions. $^{5}$

Given such a troubled landscape of federal school desegregation jurisprudence, it is not surprising that in the last thirty years, and even more so in the last decade, there has been a powerful debate over the efficacy and potency of the integrationist ideal as a means for increasing equality of educational opportunity and as a tool for broad racial reform. Increasingly, academics have mounted critiques of the Brown strategy and the failure of that decision to fundamentally transform a nation. One such critique attacks the integrative ideal as an effective strategy for achieving equality of educational opportunity. ${ }^{6}$ In the twenty-first century, however, we have a significant body

4. Missouri v. Jenkins, 515 U.S. 70, 88-103 (1995); Freeman v. Pitts, 503 U.S. 467, 486-99 (1992); Bd. of Educ. v. Dowell, 498 U.S. 237, 245-50 (1991).

5. See infra Part II.A.

6. See infra Part III.A. (discussing Derrick Bell, Serving Two Masters: Integration Ideals and Client Interests in School Desegregation Litigation, 85 YALE L.J. 470 (1976) [hereinafter Bell, Two Masters]). 
of social science research that the courts have accepted as valid ${ }^{7}$ and that details the significant educational benefits to all students of racially integrated systems of education. ${ }^{8}$

A related critique suggests that true racial reform is only possible when the goal matches the interests of the dominant power structure. ${ }^{9}$ While I do not wholeheartedly embrace this theory, hindsight does illuminate some of the limits of the Brown legal strategy and implementation of desegregative remedies. Fifty years later, it is easier to see that the strategy used and remedies implemented were, in some ways, too simplistic to address all of the complexities inherent in such a deeply entrenched system of racial discrimination. To that end, I see two fundamental flaws in the contemporary strategy and remedies used to address the violation of rights that the Court acknowledged in Brown. The first flaw lies in the use of the integrationist ideal as the sole legal hook on which to hang the proverbial hat. By relinquishing a corresponding push for equalization of resources, advocates were less able to address the deeply entrenched racial hegemony that continued to manifest itself in poorly resourced predominantly minority schools long after Brown. Secondly, by seeking a one-dimensional remedy that simply eliminated de jure segregation, advocates addressed the symptoms of racial segregation and discrimination without actually attacking its underlying causes. The failure to incorporate a holistic set of desegregative measures beyond the simple racial balancing of schools allowed for a system that, left unfettered, actually served to reinforce a system of devaluing African-American students.

I argue that advocates should have used a two-string bow strategy, using critical approaches that would have moved beyond the one-dimensional strategy employed in Brown and the one-dimensional remedy sought in the wake of the decision. The strategy should have been, and should be now, a co-extensive fight for equality in resources and true integration. True integration requires an end to the legal structure of apartheid plus the institution of holistic measures to break down attitudes that linger from a history of racial subordination. It speaks to our hope for the future and our ideal of what our society should be. It requires instituting measures that address what to do with students once they are housed in desegregated

7. See, e.g., Comfort v. Lynn Sch. Comm., 263 F. Supp. 2d 209, 234-38 (D. Mass. 2003), amended by 283 F. Supp. 2d 328 (D. Mass. 2003), and aff'd en banc, 418 F.3d 1 (1st Cir. 2005); see also Grutter v. Bollinger, 539 U.S. 306, 330-32 (2003).

8. See infra Part III.B.

9. See infra Part III.A. 
schools. ${ }^{10}$ This includes systemic efforts to dismantle the structure of racial subordination and white hierarchy. To create a more inclusive society, remedies must be as complex, long-term, and broad as the problems they seek to address. For purposes of effectuating racial reform within schools, these measures could include curricular innovations, professional training, and nonacademic opportunities designed to increase meaningful cross-racial interaction among students and teachers. ${ }^{11}$

Acknowledging both the successes and the limits in the vision and implementation of Brown may help advocates navigate the legal waters of the future and promote education-oriented strategies in the twenty-first century. In this way, the Supreme Court's recent decision in Grutter v. Bollinger, ${ }^{12}$ upholding race-conscious admissions policies in higher education, represents a vehicle to use holistic integrative policies to create and maintain access to equal educational opportunity at all levels. Beyond whatever doctrinal shift in education law that Grutter may portend more broadly, the context of K-12 public education provides a particularly compelling argument for the necessity of integrative measures. While in earlier jurisprudence, the Supreme Court has often refused to acknowledge the link between historic and current patterns of residential and educational segregation, ${ }^{13}$ or the impact of racial isolation on opportunities to learn and on academic achievement, Grutter represents the Court's most hopeful pronouncement on race in the last thirty years. To date, at least two appellate courts have reviewed the constitutionality of voluntary race-conscious programs at the K-12 level in light of Grutter, each reaching a different conclusion. I argue that advocates, educators, and policymakers should capitalize on Grutter's positive ruling on race-conscious measures in education to help further voluntary race-conscious programs at the K-12 level that both decrease racial isolation through holistic measures and push for equality through increased expenditures for those schools most in need.

Part I of this paper provides a brief history of the school desegregation litigation in the years following the Brown decision to show how the federal courts, the very institutions that gave the most hope for an integrated society,

10. See, e.g., James Moody, Race, School Integration, and Friendship Segregation in America, 107 Aм. J. Soc. 679, 713 (2001) (concluding that cross-racial integration was achieved mainly in desegregated schools that had additional opportunities for cross-racial interaction such as extracurricular activities).

11. See infra Part III.C. 2 and note 162 (noting that very little such training was provided in the wake of Brown). For a discussion of other examples of companion structures, see discussion infra Part IV.A. (voluntary integration plan of Lynn, Massachusetts).

12. 539 U.S. 306 (2003).

13. See infra Part II.A. 
actually hindered efforts to increase equal educational opportunities. Part II examines the effects of these key Supreme Court school decisions on educational opportunities and provides insights into how advocates currently use long-standing desegregation cases to address new forms of racial discrimination in public schools, as well as the limits to these strategies. Part III of this paper briefly addresses one of the more popular arguments asserting the inadequacy and futility of Brown and outlines the ways in which the onedimensional legal strategy that led to Brown and the implementation of a onedimensional remedy may have ultimately proved too simplistic to address the complexities inherent in dismantling a system of legal apartheid in our public schools. Part IV uses this understanding of historic imperfections to suggest methods for effectuating equality and racial inclusion today through voluntary race-conscious programs at the K-12 level that should be viewed even more positively in light of Grutter, the Supreme Court's most recent pronouncement on racial inclusion in education. ${ }^{14}$

\section{The Elusive Goal of School Integration}

\section{A. Massive Resistance}

Nineteenth century civil rights leader Frederick Douglass said, "[P]ower concedes nothing without demand." 15 Nowhere was this more evident than in the struggle to rid the public schools in the American South of the plague of state-enforced segregation. In the wake of the Supreme Court's decision in Brown, the power structure of the South, and indeed, every level of federal government, made few concessions in the struggle to revamp America's divided educational institutions. Under the guise of states' rights and local control, communities violently protested desegregation and created wellorganized and well-funded resistance movements. White Citizens' Councils, formed by prominent Southern bankers, doctors, lawyers, state legislators, and businessmen, exerted political and economic pressure on civil rights advocates. In 1956, every congressman and all but three Southern senators

14. It is undisputed that the Brown legal fight was not only about providing quality educational opportunities to African Americans, but also about the broader notion of equality in American society. For the purposes of this piece, however, I focus on the specific impact of the opinion on the provision of educational opportunities. This discussion also focuses on litigation under the Federal Constitution rather than state-based litigation.

15. Frederick Douglass, 1849 Letter to an Abolitionist Associate, in Organizing For SociaL Change: A Mandate For Activity In The 1990s (V.K. Bobo et al. eds., 1991). 
from the eleven states of the old Confederacy signed the "Southern Manifesto" that pledged to overturn Brown. ${ }^{16}$ Meanwhile, the Executive Branch maintained public silence, while privately condemning the Supreme Court's decision and seeming evisceration of "states' rights."

Perhaps most damaging, the High Court itself waited a full year to provide its directive on how to implement its ruling, and then provided only the vaguest guidelines. ${ }^{18}$ Lower courts either interpreted Brown narrowly or agreed to delay desegregation plans due to threats of violence. This further empowered Southern schools to resist desegregation. ${ }^{19}$

In Prince Edward County, Virginia, one of the five cases included in the Brown decision, ${ }^{20}$ the school district went so far as to close public schools altogether rather than permit desegregation. These schools remained closed for five years. ${ }^{21}$ When a Virginia court declared the practice unconstitutional, the legislature repealed compulsory education laws and made school attendance optional. ${ }^{22}$ The Virginia legislature then enacted one of the earliest voucher programs, by allocating public monies for white students to use to attend private schools, so as not to have to attend schools with black children. $^{23}$

16. See, e.g., Jack Greenberg, Crusaders in the Courts 213-17 (1994); Fred Powledge, Free AT LAST? 139-40 (1991).

17. President Eisenhower, a steadfast believer in the "functional" motives behind the Plessy v. Ferguson, 163 U.S. 537, 548-57 (1896), doctrine of "separate but equal," privately condemned the Court's ruling in Brown and promised Southern leaders that he would "make haste slowly." See, e.g., KenNETH O’Reilly, Nixon's Piano: Presidents and Racial Politics From Washington to Clinton 169-70 (1995). Eisenhower failed to take a position in most all of the high-profile civil rights battles that occurred during his administration, including the Montgomery Bus Boycott, the battle to desegregate the University of Alabama, and the lynching of fourteen-year-old Emmett Till in Money, Mississippi for allegedly whistling at a white woman. Id. at 171-72.

18. See Brown II, 349 U.S. 294, 301 (1955).

19. See, e.g., Cooper v. Aaron, 358 U.S. 1, 17-20 (1958) (holding Arkansas Governor Orval Faubus and the state legislature were bound to the Brown decision and must not delay implementation of a desegregation plan). The daybefore a desegregated Little Rock Central High was to open, Governor Faubus announced on television and radio that he had called out the Arkansas National Guard with directions to block black students' entrance into the schools; Faubus maintained that if black students actually attended school with whites, "“[b]lood [would] run in the streets." GREENBERG, supra note 16, at 229.

20. The other districts included Topeka, Kansas; Clarendon County, South Carolina; Wilmington, Delaware; and Washington, D.C. See generally Brown II, 349 U.S. 294 (1955).

21. S. Mitra Kalita, Reflecting on Lost Opportunities; School Closings During Massive Resistance Limited Black Virginians' Lives, WASH. Post, Mar. 4, 2004, at B1. This occurred in many school districts throughout the South. In Norfolk, Virginia, for example, 10,000 white and black students were shut out of public schools for several months in 1958. Mike Gruss \& Philip Walzer, Pioneers of Progress, VIRGINIANPilot \& Ledger Star (Norfolk, Va.), Feb. 1, 2004, at A1.

22. Kalita, supra note 21.

23. Id. 
It is no wonder then, that a full decade after the Brown decision, 98 percent of black students in Southern states still attended fully segregated schools. ${ }^{24}$ The Southern power structure, having had few demands placed on it by the courts, had conceded nothing, and the struggle to dismantle a system of racial hegemony continued. ${ }^{25}$

\section{B. Litigating for More Expedient Reform}

Such delaying tactics by school authorities necessitated a push by civil rights litigators to advocate for a more substantive definition of the types of remedial measures required by Brown. While Brown I was revolutionary in its statement that "separate but equal has no place" 26 in the field of public education, the Court essentially equivocated in Brown II, and thus failed to offer effective guidance on how to accomplish this goal. In the absence of clear guidance from the Supreme Court, civil rights attorneys pushed to create a legal framework that might bring the constitutional promise of Brown to bear on the harsh realities of racial inequities in America. In the late 1960s and early 1970s, civil rights attorneys brought a series of cases in federal court against individual school districts to push the Court's integration mandate. ${ }^{27}$ In 1968, some fourteen years after Brown, a unanimous Supreme Court held that freedom-of-choice plans placed an undue burden on black schoolchildren and were unacceptable where more expedient and effective methods of desegregation were available. ${ }^{28}$ Delay was "no longer tolerable," 29 and the Court imposed an "affirmative duty" ${ }^{30}$ on school districts to eliminate the

24. Erica Frankenberg et al., The Civil Rights Project, Harvard Univ., A Multiracial Society with Segregated Schools: Are We Losing the Dream? 17 (2003), available at http://www.civilrightsproject.harvard.edu/research/reseg03/AreWeLosingtheDream.pdf.

25. The passage of the Civil Rights Act of 1964 prohibiting discrimination in all programs receiving federal aid, and authorizing the Department of Justice to sue on behalf of minorities if discrimination occurred, provided the government with the enforcement powers necessary to begin a true dismantling of the apartheid system in American public schools. 42 U.S.C. $\S 2000(c)(6)$ (2000). Yet, President Nixon consciously thwarted desegregation efforts. See, e.g., Richard Kluger, Simple Justice 761-64 (2d ed. 2004). Nixon's campaign platform included opposition to desegregation orders; indeed, he ended this exercise of power in 1969, leaving the duty to ensure compliance to the courts. $C f$. Adams v. Richardson, 480 F.2d 1159, 1164-65 (D.C. Cir. 1973) (observing the Executive Branch's lengthy delay in enforcing desegregation of institutions of higher education through Title VI).

26. Brown v. Bd. of Educ., 347 U.S. 483, 496 (1954).

27. See, e.g., Green v. County Sch. Bd., 391 U.S. 430 (1968).

28. Id. at 430

29. Id. at 438 .

30. Id. at 437 . 
vestiges of discrimination "root and branch." ${ }^{31}$ The Court explicitly identified the areas in which eliminating desegregation was of the utmost importance-student assignment, facilities, staff assignment, faculty assignment, extracurricular activities, and transportation. ${ }^{32}$

In 1971, the Court gave further contours to the meaning of desegregation in Swann v. Charlotte-Mecklenburg Board of Education. ${ }^{33}$ In that case, a unanimous Supreme Court granted district courts ample freedom to fashion remedies to desegregate schools. ${ }^{34}$ These included court-mandated busing, the redrawing of attendance zone lines, and the use of mathematical ratios to ensure acceptable levels of desegregation. ${ }^{35}$ The Court also acknowledged the compounding effect that residential segregation had on educational segregation. ${ }^{36}$

In 1973, almost twenty years after Brown, the Court extended the mandate of desegregation to the North and West, where there had been no explicit statutes requiring segregation. In Keyes v. School District No. 1, Denver, Colorado, ${ }^{37}$ the Court held that, in districts where school officials had instituted segregated schools in one area, the district had an affirmative duty to desegregate all the city's schools. The ruling also recognized Latinos' right to desegregation. ${ }^{38}$

Cases like Swann and Keyes signaled a high point in American jurisprudence, when federal courts actively examined remedial plans and the scope of the courts' remedial authority to achieve integration. These cases, decided between fourteen and twenty years after Brown, marked the zenith of the judiciary's exercising of its authority over the intransigent Southern power structure. Thus, well over a decade after the court struck down state-mandated segregation, the courts at last issued orders that forced school districts to expediently begin the task of making real the constitutional promise of equal protection. By defining the contours of integration in these key decisions, the Court precipitated a steady desegregation of American schools that continued,

31. Id. at $437-38$.

32. Id. at 435 .

33. 402 U.S. 1 (1971).

34. Id. at 21 .

35. Id. at $22-32$.

36. The Court found that planned segregation of schools led to segregated housing. Id. at 20-21.

37. 413 U.S. 189, 201-04 (1973).

38. In that same year, a federal court held that the Department of Health, Education, and Welfare must issue enforcement proceedings against institutions of higher learning that failed to develop desegregation plans in compliance with Title VI of the Civil Rights Act of 1964. Adams v. Richardson, 480 F.2d 1159, 1164-65 (D.C. Cir. 1973). 
particularly in the South, for the next twenty years. ${ }^{39}$ True to Frederick Douglass's words, the Southern power structure conceded only in response to the federal court demands, which resulted in part from the continued efforts of civil rights litigators. ${ }^{40}$

\section{The First Wave of Judicial Retreat}

Unfortunately, this late-coming enforcement in the South, and brief enforcement in the North, was quickly followed by two opinions that sharply curtailed the expansion of desegregation to Northern metropolitan areas and diminished the remedies available for increasing educational opportunities for low-income minority children. In 1973, the Supreme Court, reshaped by four Nixon appointments, severely curbed the judicial remedies available to lowincome and minority students in educationally disadvantaged schools in its ruling in San Antonio Independent School District v. Rodriguez. ${ }^{41}$ In Rodriguez, the Court held that the U.S. Constitution does not create a fundamental right to an education and that wealth does not define protected classes; as such, there is no requirement that schools in richer versus poorer areas receive equal funding. ${ }^{42}$

This decision marked a retreat from Brown's commitment to equality of educational opportunity. The Court refused to address the real issue in Rodriguez-whether a state scheme that allowed for educational funding disparities caused by variations in district property wealth was unconstitutionally discriminatory under the Fourteenth Amendment's Equal Protection Clause. Indeed, even before Brown, the Supreme Court had recognized that inequality in educational facilities might be a violation of the Equal Protection Clause. ${ }^{43}$ In Rodriguez, however, the Court minimized the importance of financing variations to educational equity, even though, as Justice Marshall noted, the Equal Protection Clause is meant to address just such instances of "unjustifiable inequalities of state action."

39. See, e.g., Gary Orfield \& Chungmei Lee, The Civil Rights Project, Harvard Univ., Brown at 50: King's Dream or Plessy's Nightmare? 20 (2004), available at http://www. civilrightsproject.harvard.edu/research/reseg04/brown50.pdf. See also infra Part II.A.

40. See generally GREENBERG, supra note 16.

41. 411 U.S. 1 (1973).

42. Id. at 33-40.

43. See Sweatt v. Painter, 339 U.S. 629, 633-34 (1950) (striking down state-enforced segregation of a law school); see also McLaurin v. Oklahoma State Regents for Higher Educ., 339 U.S. 637, 642 (1950).

44. Rodriguez, 411 U.S. at 89 (Marshall, J., dissenting). 
The next year, the Court effectively ended the expansion of desegregation law, particularly for Northern and Western metropolitan areas, by signaling the preeminence of local control principles. In a 5-4 vote, the Court in Milliken v. Bradley ${ }^{45}$ struck down a desegregation plan in metropolitan Detroit and cited the importance of preserving local control of education. The Court held that there could be no inter-district remedy absent a showing of an intentional inter-district violation, or a showing that both urban and suburban school districts intentionally racially discriminated against minority students. ${ }^{46}$ This holding signaled a significant departure from the Court's decision in Keyes only one year before. As in Keyes, the constitutional violation in Milliken was the intentional segregation of the Detroit city schools. Yet, rather than ordering "all-out desegregation," inter-district relief, which was the only route to successfully desegregating the segregated schools in Detroit's urban core. The Court's decision to strike down such remedies allowed white flight to flourish, thus shaping the racial patterns of schools in metropolitan areas throughout the Northern and Western United States. These decisions also allowed the flowers of federalism, states' rights and local control to start to bloom again in the body politic.

In a companion case decided three years later and commonly known as Milliken $I I,{ }^{48}$ a unanimous Court required states to fund remedial and compensatory education programs as part of the desegregation decree. While the push for remediation was a positive directive, the Court also relinquished its commitment to eliminate the vestiges of racial segregation from schools and to push for integrating student bodies. This shift away from integrative remedies altered the nature of desegregation orders. Rather than make it extremely difficult for districts to achieve equality through integration, it instead limited the options to seeking adequacy through remedial funding of segregated schools.

\section{Retrenchment in 1990s Jurisprudence}

Although the Supreme Court initially allowed desegregation to continue in the South, it also began to curtail desegregation remedies there in the 1990s, a mere twenty years after Swann. In the 1990s, a conservative Court led by

\footnotetext{
45. 418 U.S. 717,741 (1974).

46. Id. at 744-45.

47. Keyes v. Sch. Dist. No. 1, Denver, Colo., 413 U.S. 189, 214 (1973).

48. Milliken v. Bradley II, 433 U.S. 267, $286-87$ (1977) [hereinafter Milliken II].
} 
Chief Justice Rehnquist ${ }^{49}$ essentially relinquished its obligation to require school districts to remedy racial segregation. The Rehnquist Court issued a trilogy of opinions that severely limited the circumstances, means and duration of desegregation remedies. While the Supreme Court had curtailed the financial equalization of schools and rejected metropolitan desegregation in its Rodriguez and Milliken decisions of the early 1970s, the Court also severely hampered all desegregation remedies in the landmark decisions Board of Education of Oklahoma City v. Dowell, ${ }^{50}$ Freeman v. Pitts, ${ }^{51}$ and Missouri v. Jenkins. ${ }^{52}$

In Dowell, the Court held that once a "unitary" system could be established, a federal court's desegregation order should end, even if this meant a resegregation of schools. ${ }^{53}$ The Court held that school boards need only show they complied in "good faith" and that "the vestiges of past discrimination had been eliminated to the extent practicable." ${ }^{54}$ As such, the Court declared this Oklahoma school district to be unitary and lifted the federal court order despite the fact that the district had not begun desegregating until a full eighteen years after Brown and there was no evidence that it would continue its efforts on a voluntary basis. ${ }^{55}$ In so doing, the Court disavowed any accountability for persistent racial injustice.

One year later, the Court reiterated in Pitts that "[r]eturning schools to [local control] at the earliest practicable date is essential to restore their true accountability in our governmental system. ${ }^{.56}$ To that end, the Court held that once a district complied with a portion of a desegregation order, a federal court should cease to monitor that portion and remain involved only as to those aspects of the plan that have yet to be achieved. ${ }^{57}$ This allowed for the piecemeal dismantling of desegregation orders across the South. The Court had failed to view the ramifications of segregated schools holistically. The Court thus reinterpreted the six factors that it had devised in Green v. County

49. While serving as a law clerk to Supreme Court Justice Jackson in 1952 and 1953, Rehnquist authored a memo stating that he believed "Plessy v. Ferguson was right and should be affirmed." KLuger, supra note 25 , at 606 .

50. 498 U.S. 237 (1991).

51. 503 U.S. 467 (1992).

52. 515 U.S. 70 (1995).

53. 498 U.S. at $248-49$.

54. Id. at 249-50.

55. Id. at 251 .

56. 503 U.S. at 490 .

57. Id. at 490-91. 
School Board ${ }^{58}$ to show school districts the areas in which they should focus desegregative efforts; instead, these factors became the markers by which a district could make a piecemeal argument as to the "unitariness" of one particular area. Much as Brown's message that "separate but equal has no place" has been undermined by present-day rhetoric that the ruling intended all programs to be color-blind, Green's message to desegregate in several key areas has been subverted by the Court's incremental "unitary" status determinations that Pitts permits.

The Rehnquist Court dealt the final coup de grace in Missouri $v$. Jenkins..$^{59}$ In an opinion that has little grounding in historical reality, the Court established the requirement that lower courts must specify exactly what educational deficits are traceable to segregation and discrimination, and what results will be required as proof that the deficits are remedied. ${ }^{60}$ If such specification is absent, Jenkins gives courts the license to return school districts to local control, thus allowing documented inequities to persist. ${ }^{61}$ Among other things, this opinion also released the state and local districts from paying for remedial programs. As Justice Ginsburg stated in her dissent, the Kansas City, Missouri, School District did not issue its first remedial order until three decades after Brown. ${ }^{62}$ Given such a firmly entrenched history of racial discrimination spanning more than two centuries, ${ }^{63}$ "to curtail desegregation at [that] time and in [that] manner [was] . . too swift and too soon." 64

The lie behind this glorification of local control is similar to the Court's embracing of "color blindness" in other contexts. The standard treats whites and blacks as if they were on equal footing and ignores the history of segregation and its vestiges. Moreover, the Court's grim ruling surpassed the damage caused by the curtailment of desegregative remedies in Milliken I.

58. The Court listed student assignments, facilities, staff assignments, faculty assignments, extracurricular activities, and transportation as the most critical areas with respect to desegregation. Green v. County Sch. Bd., 391 U.S. 430, 435 (1968).

59. 515 U.S. 70 (1995).

60. Id. at $97-98$.

61. Id. at $100-02$. 1985)).

62. Id. at 176 (Ginsburg, J., dissenting) (citing Jenkins v. Missouri, 639 F. Supp. 19 (W.D. Mo.

63. While the remedial programs at issue in Jenkins had been in place for only seven years, the State of Missouri has a long and well-documented history of racial subjugation, including slavery, slave-era "compulsory ignorance" laws forbidding the education of blacks and state-sponsored racial segregation. Id. at 175 (citations omitted).

64. Id. at 176 . 
While Milliken hindered mandatory metropolitan desegregation efforts, Jenkins struck down a voluntary metropolitan school desegregation plan.

The opinions of the Rehnquist Court reflect a choice. The conservative majority of the Court chose to consider the constitutional harms suffered by minority students to be less significant than restoring the authority of local agencies to run schools free of federal oversight. The Court reiterated its desire to end federal court supervision and restated the common mantra of restoring control to local school systems. This very form of local control allowed segregation to flourish in the era before Brown, and has done so again in the decade since these decisions.

\section{Current Legal and Educational Landscape}

\section{A. Result of the Court's Abandonment of the Desegregation Doctrine}

Notwithstanding the desegregative gains resulting from the jurisprudence during the first twenty years after Brown, the Supreme Court's trio of opinions in the 1990s thwarted this integration process. These decisions also have made it even more challenging to address the manifold issues that have arisen in the school desegregation context, as well as the modern mechanisms that school districts and individuals have devised to evade court orders. In the wake of these rulings, judges have returned cases sua sponte to court calendars, with the expectation that the victims of the constitutional wrongs must prove that the vestiges of the segregated system persist, or face dismissal of the case. School districts that voluntarily sought to retain desegregation plans became subject to lawsuits from groups who opposed such plans. This was precisely what happened to the school district involved in the famous Swann v. Charlotte-Mecklenburg case. ${ }^{65}$ Under Dowell, school districts need only show that they have made "good faith" attempts to remove the vestiges of discrimination to the extent practicable ${ }^{66}$ a nearly impossible standard for plaintiffs to disprove. Local institutions need only wrap their arguments in the guise of "good faith" to show that they should be released from court supervision. As a result of the Court's latest desegregation rulings, if a largely segregated school system can point to any aspect of its system that is somewhat desegregated, or if it argues that existing segregation is the result

65. Belk v. Charlotte-Mecklenburg Bd. of Educ., 269 F.3d 305 (4th Cir. 2001) (describing the district's history in the desegregation context) (citing Swan v. Charlotte-Mecklenburg Bd. of Educ., 402 U.S. 1 (1971)).

66. Bd. of Educ. v. Dowell, 498 U.S. 237, 249 (1991). 
of private housing choices rather than intentional discrimination, it may be granted partial or complete unitary status.

In essence, efforts to hold state and local institutions accountable for the effects of past discrimination have been hobbled by federal courts' determinations that the "fruits" of such discrimination fall too far from the proverbial tree-that they are too attenuated to justify race-conscious remedies. Most importantly, and most ironically, courts have held that racially segregated systems are the product of private choices, rather than state action. This is especially apparent in Justice Thomas's concurrence in Jenkins. He echoed a refrain from opinions of the nineteenth century when he mused that only state-enforced segregation was unlawful and that de facto segregation was neither inherently unconstitutional nor harmful to African Americans. ${ }^{67} \mathrm{He}$ noted that continued racial isolation might be the result of voluntary housing choices and other private decisions:

[I]t is beyond the authority and beyond the practical ability of the federal courts to try to counteract these social changes. ... [N] eutral policies, such as local school assignments, do not offend the Constitution when individual private choices concerning work or residence produce schools with high black populations. The Constitution does not prevent individuals from choosing to live together, to work together, or to send their children to school together, so long as the State does not interfere with their choices on the basis of race. ${ }^{68}$

The detrimental effects of Jenkins are evident in a recent decision ending court supervision of public school desegregation efforts in the small Southern town of Gadsden, Alabama. In Gadsden, the site of a long-standing desegregation case ${ }^{69}$ public schools have been slow to desegregate, in part due to the school district's continued resistance. As an example, the district named one middle school after the first imperial wizard of the Ku Klux Klan ${ }^{70}$ and refused to engage in any meaningful discussions with the AfricanAmerican community about the harmful effects of sending African-American children to a school with such a name. Yet, in 2000, a district court judge declared the school district unitary, and found that the level of interracial cooperation in Gadsden compared favorably with factional relations "in

67. Missouri v. Jenkins, 515 U.S. 70, 115-16 (1995) (Thomas, J., concurring).

68. Id. at 118, 121 (Thomas, J., concurring) (emphasis added) (citations and quotations omitted).

69. Miller v. Bd. of Educ., 482 F.2d 1234 (5th Cir. 1973).

70. See, e.g., Howard Ball, A Defiant Life 3 (1998); Jack Hurst, Nathan Bedford Forrest (1994); Lynne Olson, Freedom's Daughters 340 (2001). 
Kosovo and Northern Ireland." board cannot "require the lion to lay down with the lamb." 72

This judicial philosophy evidenced in Thomas's Jenkins concurrence and in the Gadsden, Alabama case is similar to the one embraced by the Court more than a century ago, in the Civil Rights Cases $^{73}$ of 1883, and in the notorious "separate but equal" decision of Plessy v. Ferguson. ${ }^{74}$ In the Civil Rights Cases, the Court struck down the Civil Rights Act of 1875, which had outlawed racial segregation in public accommodations. ${ }^{75}$ After two centuries of systemized racial persecution in which state and federal resources were used to safeguard and maintain the institution of slavery, the Court determined that the "private wrong" of racial segregation in public accommodations was beyond the reach of the Fourteenth Amendment: "[The Fourteenth Amendment] does not authorize Congress to create a code of municipal law for the regulation of private rights. ${ }^{976}$ Justice Bradley further argued that:

[I]t would be running the slavery argument into the ground to make it apply to every act of discrimination which a person may see fit to make as to the guests he will entertain, or as to the people he will take into his coach or cab or car, or admit to his concert or theatre, or deal with in other matters of intercourse or business. ${ }^{77}$

Like their nineteenth century predecessors, Dowell, Pitts, and Jenkins are distanced from the real effects that racial discrimination and subordination have on the educational opportunities of children who have historically been denied such opportunities. In these cases, the Court also refused to acknowledge the link between historic and current patterns of residential and

71. Miller v. Bd. of Educ., No. 63-AR-574-M, slip op. at 9-10 (N.D. Ala. Mar. 21, 2000). The Eleventh Circuit Court of Appeals subsequently reversed this decision and remanded the case to district court. See Miller v. Bd. of Educ., 273 F.3d 397 (11 th Cir. 2001) (unpublished opinion). The school district remains under a revised consent decree.

72. Miller, No. 63-AR-574-M, at 9-10.

73. 109 U.S. 3 (1883).

74. 163 U.S. 537 (1896). Without an acknowledgment of the very recent history of slavery and present-day realities, the Court disregarded the purpose of the Fourteenth Amendment and concluded:

Legislation is powerless to eradicate racial instincts, or to abolish distinctions based upon physical differences, and the attempt to do so can only result in accentuating the difficulties of the present situation. If the civil and political rights of both races be equal one cannot be inferior to the other civilly or politically. If one race be inferior to the other socially, the Constitution of the United States cannot put them upon the same plane. Id. at 551-52.

75. Civil Rights Cases, 109 U.S. at 26.

76. Id. at 11 .

77. Id. at $24-25$ 
educational segregation, ${ }^{78}$ or the impact of racial isolation on opportunities to learn and on academic achievement.

\section{B. Resegregation of America's Public Schools}

These attacks on efforts to desegregate have resulted in the welldocumented "resegregation" of school districts. American public schools have been steadily resegregating for more than a decade, ${ }^{79}$ dismantling the integrative successes of hundreds of districts that experienced significant levels of integration in the wake of Brown and its progeny. ${ }^{80}$ Racial isolation in public schools is worse today than at any time in the last thirty years. ${ }^{81}$ Almost all of the nation's largest urban school districts are overwhelmingly nonwhite. $^{82}$ These nonwhite schools educate one-sixth of the nation's African-American students and one-quarter of its Latino students. ${ }^{83}$ Yet, the most segregated of all students are white students. ${ }^{84}$

Educators and advocates litigating school desegregation cases today are aware that the statistics detailing school resegregation portend much more than a racial balkanization of schools at a superficial level. Beneath these statistics, the reality is that a disproportionate number of the schools in which black and brown children are educated also host ills that impede positive learning. As the old saying goes, "green follows white." The public schools that house the highest percentages of African-American and Latino students are also those that have concentrations of enormous poverty ${ }^{85}$ and very limited resources. In 2000, nearly 90 percent of intensely segregated AfricanAmerican and Latino schools had more than half of their students on free or

78. See, e.g., Nancy A. Denton, The Persistence of Segregation: Links Between Residential Segregation and School Segregation, 80 Minn. L. Rev. 795 (1996); Marc Seitles, The Perpetuation of Residential Racial Segregation in America: Historical Discrimination, Modern Forms of Exclusion, and Inclusionary Remedies, 14 J. LAND UsE \& ENV. LAW 89, 123 (1996).

79. See, e.g., ORFIELD \& LEE, supra note 39 , at 2-4.

80. During the period from 1964 to 1970 when the judiciary and the executive agencies actively enforced desegregation the percentage of African-American students in white schools increased more than fourteen-fold in six years. Id. at 18. Indeed, from 1964 to 1974, the percentage of African-American students attending previously all-white schools increased from 2.3 percent to 36 percent. $I d$. at 19 . Over the next eighteen years, the increase in the number of African-American students in white schools was approximately 33 percent. $I d$.

81. See, e.g., Frankenberg et Al., supra note 24, at 4-5.

82. Id.

83. $I d$.

84. On average, white students attend schools where 80 percent of the student body is white. $I d$.

85. Roughly one-third of African Americans live in poverty, compared to less than 10 percent of whites. Joseph Dalaker, U.S. Census Bureau, Poverty in the United States, 2000, at 4 (2001). 
reduced lunch. ${ }^{86}$ Conversely, 96 percent of white students are educated in schools with middle-class majorities. ${ }^{87}$ For those white students, the socioeconomic realities translate into better facilities, more computers, more experienced teachers, and a more diversified curriculum. For many students of color, this "green follows white" phenomenon may literally mean the difference between attending a four-year college and entering a lucrative profession, and dropping out of high school with little hope of stable employment. While there have been arguments that the proper solution should have been and should be to attack economic segregation in schools rather than attacking racial segregation per $s e{ }^{88}$ such strategies for equity in expenditures, without a corresponding push for racial integration, could not have yielded the short- and long-term educational benefits of past desegregation efforts and those that remain in place today. ${ }^{89}$

\section{Insights on Current School Desegregation Litigation}

While many school districts are prematurely phasing out desegregation plans as a result of the Court's recent rulings, schools today also manifest new forms of racial inequity that have roots in the historic systems of school segregation. There has been a metamorphosis in the way racial discrimination has expressed itself in public education. This metamorphosis illustrates that the underlying inequality that informed racial separation in schools historically remains an undeniable facet in public education today. While

86. FRANKENB ERG ET AL., supra note 24, at 35 .

87. Gary Orfield, The Growth of Segregation, in Dismantling Desegregation 53 (Gary Orfield et al. eds., 1996). The complex factors that have contributed to the crippling racial and spatial isolation of African Americans is rooted in this country's history of federal, state, local and private discriminatory housing and lending policies, and the continued effects of such policies. See, e.g., ARnOLD R. Hirsch, Making the Second Ghetto: Race and Housing in Chicago, 1940-1960, at 254-55 (2d ed. 1998); Kenneth T. Jackson, Crabgr ass Frontier: The Suburbanization of the United States 196-218 (1985); Douglas S. Massey \& Nancy A. Denton, American Apar theid (1993); Melvin L. Oliver \& Thomas M. Shapiro, Wealth and Racial Stratification, in 2 America Becoming: RaCial Trends and Their Consequences 241 (Neil Smelser et al. eds., 2001); Glenda G. Sloane, Creative Financing and Discrimination: Discrimination in Home Mortgage Financing, in A Sheltered Crisis: The State of Fair Housing IN the Eighties 83 (U.S. Civil Rights Comm'n ed. 1983); Leland Ware \& Antoine Allen, The Geography of Discrimination: Hypersegregation, Isolation, and Fragmentation Within the AfricanAmerican Community, in The State of Black America 2002, at 69 (Lee A. Daniels ed., 2002).

88. See infra Part III.A. See also Milliken II, 433 U.S. 267, 280-81, 288-90 (1977) (requiring states to fund remedial and compensatory education programs in lieu of inter-district integrative remedies) (discussed supra Part II.B.); Richard Kahlenberg, The Remedy: Class, Race, and Affirmative ACtion (1996).

89. See infra Part III. 
earlier advocates addressed the symptoms of segregation, the underlying causes of segregation continued to fester.

Over the years, court-ordered desegregation cases have shifted from efforts to eliminate the legal structure of apartheid in public schools to litigation to equalize resources between schools with largely segregated student bodies, as was the case in Milliken II, or to address in-school racial segregation that manifested in areas such as special education classes and in discipline referrals. Such issues are a direct result of the failure to fully desegregate schools in the wake of Brown, as well as the perpetuation of practices within schools that allowed racial hierarchical systems to continue to flourish.

Today, advocates use traditional desegregation cases to address many of the new forms of racial inequity that are vestiges of historical racial segregation and discrimination in public schools. A number of such cases remain active in federal courts throughout the South and provide some of the only constitutional tools to address a host of damaging issues. Ironically, the language of Brown assumed schools were effectively equal: "[T]here are findings below that the Negro and white schools involved have been equalized, or are being equalized, with respect to buildings, curricula, qualifications and salaries of teachers, and other 'tangible factors." ${ }^{90}$ Yet, such equalization has remained elusive. Indeed, traditional desegregation cases are often used today as vehicles for the Plessy-like equalization of facilities, curricula, and other "tangible factors" plaguing school districts where integration has been effectively abandoned.

By obtaining and preserving consent decrees in school districts, advocates have affected the holistic education of children in public schools by, among other things, helping to create magnet programs, addressing racial disparities in the identification of special education students, ${ }^{91}$ tackling the disproportionate disciplining of students of color, spurring new school construction, and improving the hiring and retention of African-American teachers and staff. In turn, these decrees help to diminish the effects of segregation, deconcentrate poverty, and improve the quality of learning for

90. Brown v. Bd. of Educ., 347 U.S. 483, 492 (1954).

91. When Congress passed amendments to the Individuals with Disabilities in Education Act ("IDEA") in 1997, it found that students of color were statistically 2.3 times more likely to be identified as having special needs than their white counterparts. Individuals with Disabilities Education Act Amendments of $1997 \S 101$ (c)(8)(c), Pub. L. No. 105-17, 111 Stat. 37 (1997); see also RaCIAL INEQUALITY in Special Education (Daniel J. Losen \& Gary Orfield eds., 2002) (discussing overidentification of racial minorities in special education). 
some children of color. In Alabama, for example, a recent statewide decree requires that the State address the vestiges of racial segregation that exist in the special education context. ${ }^{92}$ Such desegregation decrees provide a vehicle to address some of the racial disparities that continue to plague students in these schools. Thus, while current litigation is limited by the Supreme Court's jurisprudence, existing court-ordered desegregation plans can still have concrete positive effects.

In addition to mandatory desegregation plans, other school districts have voluntarily instituted desegregation programs in public schools throughout the country, which use race as one of many factors in creating holistic educational programs. Such approaches circumvent some of the Supreme Court's limitations on court-ordered plans. Voluntary measures can help to reduce racial isolation both within schools and between districts. In Massachusetts, South Carolina, Kentucky, and California, advocates have successfully defended policies in which school districts have voluntarily considered the racial diversity of student bodies in determining where to build new schools, how to draw attendance zone lines, and how to fashion student transfer policies. ${ }^{93}$ When properly implemented, such policies can marry true racial integration with increased financial capital to provide improved racial and economic diversity within public education. ${ }^{94}$

\section{REFLECTIONS ON BROWN}

Fundamentally, the age-old debate about racial integration has never been simply about white students and students of color learning in the same classroom; by virtue of the Supreme Court's jurisprudence limiting other avenues for relief, integration has also been one of the only legal tools available to address overall concentrations of poverty and severe racial isolation, which hamper children's opportunities to learn. As Justice Marshall

92. Lee v. Lee County Bd. of Educ., 963 F. Supp. 1122, 1124 (M.D. Ala. 1997) (holding the Alabama State Board of Education and state superintendents responsible for maintaining dual system of education and requiring them to remove those vestiges). The parties entered into a statewide consent decree in the case in September 2000, which requires removing the vestiges of racial discrimination in provision procedures for identifying and placing students in special education in the State of Alabama. See Marilyn Milloy, Truth in Labeling, NEA TodAY, Jan. 2003, at http://www.nea.org/neatoday/0301/cover.html (discussing some early successes of reforms instituted under the Lee v. Lee County Board of Education special education decree).

93. See, e.g., Comfort v. Lynn Sch. Comm., 263 F. Supp. 2d 209 (D. Mass. 2003); see infra Part IV (discussing the merits of voluntary race-conscious programs in public education).

94. See infra Part IV. 
stated, our standard for addressing inequality in education should be rooting out "[d]iscrimination in the opportunity to learn that is afforded a child." providing increased access to quality education, schools may literally serve as the determinative factor of a child's success. The Court in Brown noted this when it stated that "education is perhaps the most important function of state and local governments .... [and] is a principal instrument in awakening the child to cultural values, in preparing him for later professional training, and in helping him to adjust normally to his environment." ${ }^{96}$

In the last thirty years, and increasingly so in the last decade, there has been a powerful debate over the efficacy and potency of the integrationist ideal as a means for increasing equality of educational opportunity and as a tool for broad racial reform. Although in the court of public opinion, Brown represents one of the most important Supreme Court decisions of the last century, there has been a mounting academic critique ${ }^{97}$ of the Brown strategy and the failure of that decision to fundamentally transform a nation. One such critique attacks the integrative ideal as an effective strategy for achieving equality of educational opportunity. ${ }^{98}$ A related critique suggests that true racial reform is only possible when the goal matches the interests of the dominant power structure. ${ }^{99}$ While I do not wholeheartedly subscribe to these theories, I do think hindsight affords us the ability to see some of the limits of the Brown legal strategy and implementation of desegregative remedies more clearly. In this section, I examine some of the more popular critiques of the integrationist strategy and argue that advocates in Brown utilized a onedimensional strategy - attacking racial segregation without a corresponding attack on unequal resources - and a one-dimensional remedy - focusing on the elimination of de jure segregation without additional measures to address the underlying causes of racial hegemony. I argue that this strategy and resulting remedy has hindered the progress of racial inclusion and equality of educational opportunity, and suggest that the fight should have focused on achieving both true integration and equality of resources.

95. San Antonio Indep. Sch. Dist. v. Rodriguez, 411 U.S. 1, 84 (1973) (Marshall, J., dissenting).

96. Brown, 347 U.S. at 493.

97. See, e.g., Michael J. Klarman, From Jim Crow to Civil Rights: The Supreme Court and the Struggle for Racial Equality 468 (2004); Michael J. Klarman, Brown, Racial Change, and the Civil Rights Movement, 80 VA. L. Rev. 7 (1994); Gerald N. Rosenberg, Brown is Dead! Long Live Brown!: The Endless Attempt to Canonize a Case, 80 VA. L. Rev. 161 (1994); Mark Tushnet, The Significance of Brown v. Board of Education, 80 VA. L. REV. 173 (1994).

98. See infra Part III.A.

99. Id. 


\section{A. The Futility of the Integrationist Strategy and the Role of "Interest- Convergence"}

There are a number of legal scholars who have discussed the ways in which the much-lauded Brown decision was, in the end, a wasted effort. Perhaps the best known of these critiques is the one espoused by Professor Derrick Bell nearly thirty years ago in his oft-cited article, Serving Two Masters. ${ }^{100}$ Bell has argued that the goal of Brown should not have been racial integration of public education. Rather, he argued that his "behind-the-scenes view" as a civil rights attorney with the Legal Defense Fund revealed that the much-lauded integrationist ideal often failed to directly address clients' interests. ${ }^{101}$ Moreover, Professor Bell argued that the legal strategy of desegregation did not provide clients with lasting remedies. ${ }^{102}$ Since, according to Bell, integration is a lofty and unattainable ideal that is often out of synch with the actual interests of African-American clients in desegregation cases, ${ }^{103}$ the legal strategy should have instead focused on education-oriented strategies, apart from a discussion of race.

Later, Bell expounded upon this theory in his discussion of the "interestconvergence" theory ${ }^{104}$ and in his recent book on the "unfulfilled hopes for racial reform." 105 According to his interest-convergence theory, racial progress only comes when the interests of the white power structure converge with the stated goal to produce the desired result. ${ }^{106}$ Bell argues that "policymakers recognize and act to remedy racial injustices when, and only when, they perceive that such action will benefit the nation's interests without significantly diminishing whites' sense of entitlement."107 As such, racial justice only arrives "on the wings of racial fortuity rather than hard-earned entitlement. Its departure, when conditions change, is preordained." 108

Such critiques of Brown and its integrationist legal strategy may be rooted in the sentiment of significant numbers of the black population during the era pre-dating Brown. There are members of the black populace who vociferously

100. Bell, Two Masters, supra note 6.

101. See id. at 471

102. $I d$.

103. Id.

104. Derrick Bell, Brown v. Board of Education and the Interest-Convergence Dilemma, 93 HARV. L. REv. 518 (1980).

105. Derrick Bell, Silent Covenants 49-58 (2004) [hereinafter Bell, Covenants].

106. $I d$.

107. Id. at 9 .

108. Id. 
advocated for a more measured approach, felt that a frontal attack on segregation was too rash, and well understood that such measures would realistically be ineffective as means to bring immediate educational improvements to black children. As Professor Bell has argued, the black and civil rights lawyers who argued fervently for integration were part of a social elite who stood to gain more than the average black American from a policy of integration. ${ }^{109}$ Yet, current critiques of the Legal Defense Fund strategy are too easily dismissive of a set of legal tactics that, while imperfect, have yielded and continue to yield substantial, long-term, transformative results. Indeed, Brown undoubtedly conveyed a powerful message of equality to many African Americans throughout the nation, as is evidenced by the welldocumented reactions to the decision. ${ }^{110}$

Importantly, these critiques fail to examine some of the real challenges that were inherent in advocating for educational opportunities for AfricanAmerican children in an era when our country still sanctioned an apartheid regime in the South. While Bell suggests that the strategy of racial integration was imprudent at best, it is essential to understand that without such a strategy, it may have been nearly impossible to push for effective educationoriented strategies in a world where African Americans' movements were so proscribed. The Supreme Court was the sole institution that could have effectively issued the clarion call that Plessy's "separate-but-equal" rule was no longer the law of the land. If the "social engineers" of Charles Hamilton Houston's vision ${ }^{111}$ had not advocated for equal justice under the law for all Americans by promoting racial integration and enlisting the law in that cause, we would likely not have the successes of today in the fields of medicine, law, business, and education. ${ }^{12}$

109. Bell, Two Masters, supra note 6, at 489-92 (noting that, in the short run, it may have been the black elites who stood to gain the most immediate benefits from breaking down the doors of state-sponsored segregation).

110. As Reverend Dr. Martin Luther King stated, for millions of people, the decision "served to transform the fatigue of despair into the buoyancy of hope." Reverend Dr. Martin Luther King, Jr., The Rising Tide of Racial Consciousness, in IHave a Dream: Writings and Speeches That Changed the World 63, 65 (James M. Washington ed., 1992); see also Lynne Olson, Freedom's Daughters: The Unsung Heroes of the Civil Rights Movement From 1830 to 1970 (2001); Powledge, supra note 16, at 57 (noting that the Brown decision was one of the critical events that gave the civil rights movement irreversible momentum).

111. Charles Hamilton Houston, noted lawyer, Howard Law School professor, and architect of the legal strategy behind Brown, espoused a philosophy of "social engineering," which argued that the law could be used as a tool for fundamental social change. See generally GenNa RaE MCNEIL, Groundwork: Charles Hamilton Houston And the Struggle for Civil Rights (1983).

112. See, e.g., KLUGER, supra note 25, at 781-82. 


\section{B. The Value of Racially Integrated Schools}

The most effective refutation of the critiques mounted by Bell and others is the substantial body of social science research, which courts have accepted as valid, that details the significant short- and long-term educational benefits of racially integrated systems. ${ }^{113}$ Substantial desegregation of students did not begin until fully seventeen years after the Court's decision in Brown-with Green and Swann. The most effective period of school desegregation took place from approximately 1970 until $1990,{ }^{114}$ when Dowell and its progeny prompted a rollback of desegregative gains. During that time, AfricanAmerican students experienced a significant rise in academic achievement. In the $1950 \mathrm{~s}$, less than 50 percent of young African-American adults had a high school diploma or a GED. ${ }^{115}$ By 1993, the rate had increased to 83 percent, which was close to the completion rate of whites. ${ }^{116}$ By the late 1980s, the graduation rate for African Americans surpassed the national secondary completion rates for most European societies. ${ }^{117}$

Likewise, the so-called "achievement gap" between African-American and white students decreased considerably. Reading, math, and science scores

113. See, e.g., Elliot Aronson \& Shelley Patnoe, The Jigsaw Classroom: Building Cooperation in the Classroom (2d ed. 1997); Janet Ward Schofield, Black and White in School: Trust, Tension, or Tolerance? (1982); Amy Stuart Wells et al., How Desegregation Changed Us: The Effects of Racially Mixed Schools on Students and Society (2004), available at http://cms.tc.columbia.edu/i/a/782_ASWells041504.pdf; Christopher Ellison \& Daniel A. Powers, The Contact Hypothesis and Racial Attitudes Among Black Americans, 75 Soc. SCI. Q. 385 (1994).

114. John R. Logan \& Deirdre Oakley, Lewis Mumford (Tr. for Comparative Urban and Reg'l Research, State Univ. of N.Y. at Albany, The Continuing Legacy of the Brown Decision: Court Action And School Segregation, 1960-2000, at 2 (2004), available at http:// mumford.cas.albany.edu/schoolsegregation/reports/Brown_report_1_28.doc. As of 2000, 75 percent of African-American students in the South and 62 percent of African-American students in the rest of the country were attending schools in districts that were under mandatory desegregation decrees at some time between 1950 and 1964. Id.

115. Gary Orfield, Unexpected Costs and Uncertain Gains of Dismantling Desegregation, in Dismantling Desegregation 85 (Gary Orfield et al. eds., 1996).

116. $I d$.

117. $I d$. at 73,85 . One example of such change includes the St. Louis desegregation case. Liddell v. Bd. of Educ., 567 F. Supp. 1037 (E.D. Mo. 1983). There, a settlement resulted in voluntary desegregation measures that allowed several thousand black inner-city youth to enroll in predominantly white systems in the suburbs. While the majority of transfer students were low-income, they completed high school at approximately twice the rate of their counterparts in racially isolated city schools and attended college at a rate three times above the national average for black high school graduates. AMY Stuart Wells \& Robert L. Crain, Stepping Over the Color Line: African-American Students in White Suburban Schools 198-99 (1997). 
of elementary and secondary students improved between 1971 and the 1980 s. ${ }^{118}$ Since school desegregation policies were widely implemented in the late 1960s, the test score gap between African-American students and white students has decreased by almost 50 percent. ${ }^{119}$ This gap closed markedly, despite the fact that many lower-achieving African-American students who would have previously dropped out of school remained in the system. Moreover, scores for African-American students improved even though the incidence of poorer, single-parent families and unemployment were on the rise. ${ }^{120}$ At least one study has found that while positive family changes such as improved parental education accounted for less than 25 percent of the reduction in the test score gap, significant changes in African-American educational opportunities brought by desegregation, the war on poverty programs, and affirmative action were most likely more related to the improvement. ${ }^{121}$ In addition, the largest changes in the test score gap occurred in the Southeast, which had experienced the highest levels of desegregation and had the largest number of districts under mandatory desegregation decrees. ${ }^{122}$ African-American gains were the lowest in the Northeast, which experienced the least amount of desegregation ${ }^{123}$ due to the Court's ruling in Milliken, striking down mandatory inter-district desegregative remedies absent a showing of intent. In addition to the statistical evidence showing that desegregated schools lead to higher graduation rates and test scores, studies show that African-American children attending desegregated schools are more likely to enroll in and graduate from four-year colleges and to major in subjects that lead to more lucrative jobs and professions. ${ }^{124}$

118. Nat'l Ctr. for Educ., U.S. Dep't of Educ., Statistics, Status and Trends in the EdUCATION OF BLACKS 48-52 (2003). Science scores for African Americans appear to have remained constant beginning in the early 1990s. Id. at 52. The gap between African-American and white students' reading scores has widened moderately beginning in the late 1980 s until 1999 . Id. at 48 . There is some evidence to suggest that the leveling off of gains in closing the test score gap might be a result of the leveling off of previous desegregative gains. See, e.g., FRANKENBERG ET AL., supra note 24, at 4-5 (citing Eric Hanushek et al., New Evidence about Brown v. Board of Education: The Complex Effects of School Racial Composition on Achievement (Nat'1 Bureau of Econ. Research, Working Paper No. 8741, 2002).

119. Wells \& CRAIN, supra note 117 , at 340.

120. ORFIELD, supra note 115 , at 86.

121. David Grissmer, Ann Flanagan \& Stephanie Williamson, Why Did the Black-White Score Gap Narrow in the 1970s and 1980s?, in THE BLACK-White TEST SCORE GAP 182, 199-200, 221 (Christopher Jencks \& Meredith Phillips eds., 1998).

122. LOGAN \& OAKLEY, supra note 114 , at 2.

123. Id.

124. James McPartland \& Jomills Braddock, Going to College and Getting a Good Job: The Impact of Desegregation, in EfFective School Desegregation: Equity, Quality, AND Feasibility 141 (Willis D. Hawley ed., 1981). 
Perhaps most importantly, data also suggests that there are long-term benefits for students who attend racially integrated schools. Beginning in the 1980 s and early 1990s, as the long-term effects of desegregation plans implemented in the late 1960s and early 1970s became more apparent, a growing body of literature detailed the long-range benefits of desegregation in America's public schools. ${ }^{125}$ As sociologists Amy Stuart Wells and Robert Crain have found, desegregation policies have provided African-American students with access to high-status institutions and the powerful social networks that grow out of those institutions. ${ }^{126}$ Yet, African-American children are not the only long-term beneficiaries of integrated schools. Studies have shown that desegregative policies benefit children of all races. Meaningful interaction between students from racially diverse backgrounds leads to an increased sense of civic engagement and increases the likelihood that such students will grow up socializing across racial boundaries and discussing racial matters. ${ }^{127}$ These benefits include greater toleration of, and appreciation for, members of other racial backgrounds, a greater sense of civic and political engagement, and an increased desire to live and work in multiracial settings as adults. ${ }^{128}$

Even in the face of formidable challenges to the use of court-ordered desegregative remedies, more than seventy-five active school desegregation and education cases remain. ${ }^{129}$ The experience of active school desegregation litigators is that such cases have provided, and continue to provide, academic and social benefits for all children in school districts. ${ }^{130}$ In the latest generation of school desegregation cases, desegregative policies have been employed to advocate for the construction of better schools, for curricular advancements, and to address a host of racial disparities in school discipline

125. See, e.g., id. at 141-44.

126. Amy Stuart Wells \& Robert L. Crain, Perpetuation Theoryand the Long-Term Effects of School Desegregation, 64 REV. EduC. RES. 531-35 (1994).

127. See, e.g., William G. Bowen \& Derek Bok, The Shape of the River 232 (1998); Schof IELd, supra note 113; Wells ET AL., supra note 113, at 14-15; Mitchell J. Chang, The Positive Educational Effects of Racial Diversity on Campus, in Diversity Challenged 175, 183 (Gary Orfield \& Michal Kurlaender eds., 2001). Even the Rehnquist Court, Shaw v. Reno, 509 U.S. 630, 648-49 (1993), noted that our Constitution encourages us to weld together various racial and ethnic communities, and to avoid racial balkanization. See also Miller v. Johnson, 515 U.S. 900, 911 (1995).

128. See Janet Ward Schofield, School Desegregation and Intergroup Relations: A Review of the Literature, 17 Rev. Educ. RES. 335, 335-409 (1991); Lee Sigelman \& Susan Welch, The Contact Hypothesis Revisited: Black-White Interaction and Positive Racial Attitudes, 71 Soc. ForCES 781 (1993); WELLS ET AL., supra note 113, at 15-18.

129. NAACP Legal Defense Fund Case Docket ii (Apr. 2004).

130. This is consistent with impressions drawn from former colleagues. 
and in special education. ${ }^{131}$ Furthermore, notwithstanding Bell's arguments about the divergence between litigation strategies and client interests, current litigation efforts may be the only viable way of addressing clients' interests, even if there is disagreement as to some of the specific aspects of relief. ${ }^{132}$ While an imperfect solution, these cases provide one of the only means by which plaintiffs can hold districts constitutionally responsible for proactively working to remove the vestiges of a history of racial subordination and segregation from public schools. Indeed, such cases arguably have provided remedies on a district-by-district basis ${ }^{133}$ that have proved elusive in other forms of school litigation to date, such as cases brought under the education clauses of state constitutions. ${ }^{134}$

\section{The Benefit of Hindsight}

Nonetheless, we are at a critical point in the evaluation of the use of traditional strategies for attacking segregation per se. Critiques of the integrationist ideal and of the forces that led to a dismantling of statesanctioned segregation in America's public schools are not without merit. With the benefit of a half-century of hindsight, the limits in the vision of Brown and the failure to fully implement effective civil rights remedies are more clear. Fifty years later, it is easier to see that the strategy used and the remedies implemented were, in some ways, too simplistic to address all of the complexities inherent in such a deeply entrenched system of racial discrimination. While the limits in the vision and implementation of Brown do not negate the very real gains we have witnessed as a result of the Court's ruling, acknowledging them may help advocates navigate the current legal climate and develop education-oriented strategies in the twenty-first century. I argue that any effective future litigation strategy should move beyond the

131. See supra Part II.C.

132. This is consistent with feedback received from my former clients and clients of former colleagues in other desegregation cases.

133. See supra Part II.C. (discussing successes of second-generation school desegregation litigation).

134. While such school finance cases may be successful at the liability phase, slow-moving state legislatures often hamper remedial implementation. See Michael A. Rebell, Education Adequacy, Democracy, and the Courts 240, in Achieving High Standards of Justice for All: Conference SUMmARY (2002), available at http://www.schoolfunding.info/resource_center/research/ adequacychapter.pdf (discussing challenges in remedial phases of school finance litigation). Moreover, with the exception of Sheffv. O'Neill, 678 A.2d 1267, 1281 (Conn. 1996), the definitions of adequacy used by the state courts do not reference race or a requirement for racial integration. 
one-dimensional approach employed in Brown and the one-dimensional remedy sought in the wake of that decision.

\section{The Limits of a One-Dimensional Strategy}

The flaw in the strategy of Brown lies in the use of the integrationist ideal as the sole legal hook on which to hang the proverbial hat. While scholars like Bell suggest that the integrationist strategy itself was misguided, this supposes that legal tacticians were faced with an either/or situation-lawyers may either fight for the dismantling of a system of legal apartheid in American public schools or they may advocate for the equalization of physical facilities, books, and curricular offerings, but not both. Indeed, in the earlier stages of the Brown litigation, strategists actually did use a "two-string bow" strategy. ${ }^{135}$ Professor Jack Greenberg, one of the lawyers who litigated the Brown cases, noted that there was tension among Legal Defense Fund lawyers regarding the decision to mount a frontal attack on segregation without a corresponding attack on unequal facilities and expenditures. According to Greenberg, some lawyers viewed a parallel strategy as potentially ineffectual, "cowardly[,] and unprincipled," while others, including Thurgood Marshall, "[u]p to the very end ... wanted to give judges an opportunity to rule with us on the basis of physical inequalities." 136 Eventually, Marshall decided to drop the equalization strategy and attack segregation per se. In the period before the high Court's ruling, however, Marshall reportedly had second thoughts about this strategic decision. ${ }^{137}$

Ultimately, the Brown Court found that the segregated schools involved "ha[d] been or [we]re being equalized, with respect to buildings, curricula, qualifications and salaries of teachers, and other 'tangible' factors." ${ }^{\text {"138 }}$ By admitting that separate schools were being equalized, lawyers lost the ability to incorporate equalization as a fundamental strain within Brown's integrationist mandate. In so doing, it became increasingly difficult to talk about integration and equalization as equally critical parts of the goal of increasing educational opportunities for African-American children. As a consequence, desegregative remedies focused more on the literal

135. Kluger, supra note 25, at 293 (discussing the Brown legal team's decision to "hedge on the strategy" by arguing that "black public schools violated the Fourteenth Amendment because they were (1) demonstrably unequal to and (2) separate from white schools in the community").

136. GreenberG, supra note 16 , at 86.

137. KLUGER, supra note 25, at 293.

138. Brown v. Bd. of Educ., 347 U.S. 483, 493 (1954). 
desegregation of schools and classrooms, and less on the equalization that remained elusive.

Fifty years after the Court's ruling regarding segregation, however, it is painfully apparent that the elimination of the legal structure of racial segregation has not been the panacea that many hoped it would be. Even in the ongoing struggle to achieve the true integrative ideal that many believed to be the spirit of the law as set forth in Brown, the fundamental reality has been that the tactic of relying exclusively on desegregating schools as the strategy for effectuating equality of educational opportunity has faltered without a corresponding focus on equalization. The current landscape with respect to educational opportunities has proven that equality of resources is equally critical to the success of many integration strategies.

The reality of educational opportunities in the twenty-first century falls far short of the ideals set forth in Brown. In their failure to continue to advocate for increased expenditures, improved physical resources, and better curricular offerings in majority black schools while desegregative remedies were being implemented, lawyers missed a vital opportunity to directly address the realities of the entrenched racial hegemony while still seeking the ideal of integrated public education. The strategy should have been, and should be today, a dual strategy of seeking both true integration ${ }^{139}$ and equality of resources. ${ }^{140}$ As a strategy, the two-string bow of integration and equalization may have yielded more effective results, and also may have preempted the attacks on the integrationist ideal that developed in the wake of the decision. ${ }^{141}$ Hindsight has shown that the law is not singularly transformative, particularly in the face of deeply entrenched racial inequities.

139. See discussion infra Part III.C.2. Professor John Powell has also discussed the concept of true integration. See, e.g., John A. Powell \& Marguerite L. Spencer, Brown is Not Brown and Educational Reform is Not Reform if Integration Is Not a Goal, 28 N.Y.U. Rev. L. \& Soc. Change 343 (2003); John A. Powell, The Tensions Between Integration and School Reform, 28 Hastings Const. L.Q. 655 (2001); John A. Powell, Living and Learning: Linking Housing and Education, 80 MinN. L. REv. 749 (1996).

140. An argument could also be made that such equalization of resources across schools may, in fact, require more significant expenditures to be allocated toward predominantly minority schools that often have high concentrations of poverty. Since schools that house students with little resources are often more expensive to operate, such schools need even greater resources than do middle- and upper-middle-class schools. See, e.g., James Ryan, Schools, Race, and Money, 109 YALE L.J. 249 (1999).

141. As noted earlier, see discussion supra Part III.A, the attacks on the integrationist ideal came about in part over the frustration of the failure of the integrationist strategy to yield sufficiently transformative results in the field of educational opportunities. Yet, if a dual strategy had been employed, the fundamental struggle for integration could have continued alongside, rather than in lieu of, a push for direct attention to the expenditures that would have more immediately addressed the needs of children in the face of the challenges to integration that ensued. 
The vestiges of this nation's history of racial subordination are particularly evident in the persistent residential segregation and concentrations of poverty that plague African Americans. In the face of such segregation and poverty, policies that addressed equalization of expenditures and curricular offerings at predominantly black schools would have helped to increase educational opportunities while addressing the realities of the day.

Larger systemic racial inequities still affect the provision of quality education in our nation. Perhaps the most egregious of these inequities is the persistent concentration of poverty and resulting residential segregation that continues to plague our nation. Since sociologist Gunnar Myrdal's critique of the "American Dilemma" of racial discrimination, ${ }^{142}$ social scientists have documented the interrelation between concentrations of poverty, segregation, and racial inequality. ${ }^{143}$ African Americans, in particular, are the most segregated group in America, even more so than poor whites. ${ }^{144}$ This pattern of segregation holds even for more affluent blacks, ${ }^{145}$ which suggests that class-based remedies alone will not eradicate inequities. The effects of governmental and private housing discrimination are still manifesting today. ${ }^{146}$ Given that the courts — save for a brief moment in time ${ }^{147}$ — have been largely unwilling to acknowledge the relationship between these factors, equalization efforts remain an imperative companion remedy. ${ }^{148}$

142. See Gunnar Myrdal, An American Dilemma: The Negro Problem and Modern DEMOCRACY 77 (Pantheon Books 1996) (1944).

143. See, e.g., Massey \& Denton, supra note 87.

144. See, e.g., John ICEland Et al., U.S. Census Bureau, Racial and Ethnic Segreg ation in the United States: 1980-2000, at 3-4 (2002); Massey \& Denton, supra note 87, at 84-87; Mary Patillo-McCoy, Black Picket Fences 27 (1999); Douglas S. Massey \& Mary J. Fischer, Does Rising Income Bring Integration? New Results for Blacks, Hispanics, and Asians in 1990, 28 Soc. SCI. Res. 316 , 317 (1999) (noting that African-Americans "continue to lag well behind other groups in achieving integration, irrespective of social class"); Mary Patillo-McCoy, Black Picket Fences 27 (1999).

145. See, e.g., Richard D. Alba et al., How Segregated are Middle-Class African Americans?, 47 Soc. Probs. 543, 556 (2000) (noting that the communities in which African Americans reside have less affluence and more crime than the communities where whites with similar personal and household characteristics are found); Massey \& Fischer, supra note 144, at 317.

146. See Civil Rights Project, Harvard Univ. \& Lewis Mumford Ctr. For Comparative Urban \& Reg' 'L Research, State Univ. of N.Y. at Albany, Housing Segregation: Causes, Effects, AND Possible Cures 2-4 (Apr. 3, 2001) (noting that fears of the "black ghetto" contribute to racial discrimination and flight from integrated neighborhoods); Denton, supra note 78, at 795, 801-06.

147. See Columbus Bd. of Educ. v. Pernick, 443 U.S. 449, 465 n.13 (1979) (noting that "school segregation is a contributing cause of housing segregation"); Swann v. Charlotte-Mecklenburg Bd. of Educ., 402 U.S. 1 (1971) (noting that planned segregation of schools led to segregated housing).

148. Efforts to increase expenditures, however, without the corresponding attention to eradicating the underlying causes of racial discrimination and segregation, also miss the point. The failure of the remedies ordered in Milliken II, for example, illustrates that a singular focus on increasing expenditures to 
The failure of the traditional desegregation strategy to incorporate a corresponding push for equality of resources means that advocates today must still fight for that elusive equality in educational opportunity. ${ }^{149}$ In many of the cases with court-ordered desegregation decrees today, advocates fight for Plessy-like equalization of resources as a direct result of the failure to do so in the past. The underlying inequality that informed racial separation prior to Brown continues to plague the nation's schools, but is manifested in other ways. Consequently, while advocates strive to decrease racial isolation in all schools, racial inequality continues to manifest in unequal physical expenditures allotted to schools in the predominantly black neighborhoods. ${ }^{150}$ In these cases, advocates use the court-ordered desegregation decrees to address racial disparities in resource allocation and curricular offerings. It could be argued that the triumph of traditional court-ordered desegregation plans is that advocates actually have a constitutional hook at their disposal with which to fight for such "equalizing" remedies. Yet, the tragedy is that if there had been a corresponding effort to include a focus on the equalization efforts along with integration in the strategy leading to the Court's decision in 1954, advocates might be much further along in addressing some of the tangible results of historical and current segregation that continue to plague public schools.

The failure of the singular focus on attacking segregation proves that the formal neutrality of a policy simply eliminating de jure segregation could not by itself ensure educational opportunities for students who have historically been denied such opportunities on the basis of race. This is the reason that the strategy should have been, and should continue to be, a co-extensive fight for equalization and true integration that includes holistic measures. ${ }^{151}$

\section{The Limits of a One-Dimensional Remedy}

Related to the abandonment of a dual equalization-integration strategy in favor of attacking only segregation, the resulting remedies ordered by the Court failed to include measures that would help to address the core objective of Brown - to reduce the racial stigmatization inherent in the system of statesponsored racial segregation and discrimination. As the Court held, "[t]o

predominantly black schools at the expense of directly addressing the root causes of racial segregation and discrimination cannot succeed. See Milliken II, 433 U.S. 267 (1977); infra Part III.C.2.

149. See supra Part II.C. (discussing current day school desegregation litigation).

150. Id.

151. See infra Part III.C.2. 
separate [black children] from others of similar age and qualifications solely because of their race generates a feeling of inferiority as to their status in the community that may affect their hearts and minds in a way unlikely to ever be undone." ${ }^{52}$ The desegregative remedies implemented in the wake of Brown focused largely on eliminating the actual system of racially separate schools, but failed to satisfactorily implement companion structures that might have helped effectuate the dismantling of a deeply entrenched system of valuing one race over another. The equitable remedies used to repair the denial of the constitutional right addressed in Brown did not effectively tackle the underlying condition that so offended the Constitution in the first place. The remedies ordered did not confront the stigmatic effect of racial segregation referenced by the Court in the legendary footnote 11 of the Brown decision, ${ }^{153}$ which detailed the social and psychological effects of a racially segregated education on minority children. Indeed, while the Court's denunciation of the state-sponsored segregative system in the South led to a slow and sometimes troubled dismantling of the legal structures of segregation, it did not result in a remedy that addressed the issue of the stigmatic harm that centuries of white supremacy wrought on black children, and on children of all races. ${ }^{154}$ In essence, the remedy ended state-sponsored segregation but failed to achieve true integration.

True integration requires an end to the legal structure of apartheid plus an institution of holistic measures to break down attitudes that linger from a history of racial subordination. It addresses our hope for an inclusive society. It requires instituting measures that also focus on helping students once they are enrolled in desegregated schools. ${ }^{155}$ This effort should include systemic efforts to dismantle the structure of racial hegemony. To create a more inclusive society, remedies must be as multifaceted as the problems they seek to address. Such integrative remedies could include curricular innovations, professional training, and non-academic opportunities designed to increase meaningful cross-racial interaction among students and teachers. ${ }^{156}$ The failure to incorporate a holistic set of desegregative measures, beyond the

152. Brown v. Bd. of Educ., 347 U.S. 483, 494 (1954).

153. Id. at 494 n.11.

154. As Professor John Charles Boger noted, racial segregation in schools worked a "terrible evil" on white children as well. John Charles Boger, Willful Colorblindness: The New Racial Piety and the Resegregation of Public Schools, 78 N.C. L. REv. 1719, 1794 (2000).

155. See, e.g., Moody, supra note 10, at 679,709 (study concluding that cross-racial integration was achieved mainly in desegregated schools that had additional opportunities for cross-racial interaction such as extracurricular activities).

156. For a discussion of other examples of companion structures, see infra Part IV.A. 
simple racial balancing of schools, allowed for a system that, left unfettered, actually served to reinforce a system of devaluing African-American students.

Certain specific tactics post-Brown reinforced patterns of racial hegemony by placing the intolerable burden of integration on AfricanAmerican students. Such policies included the "freedom-of-choice" plans first used to eradicate segregation, which placed the onus on black children to voluntarily desegregate schools, and which were used to control the extent of desegregation. ${ }^{157}$ By 1968, the Court held that such plans were unconstitutional because they placed an undue burden on African-American students. ${ }^{158}$ Yet fourteen years of such plans had already buttressed the deeply entrenched system of white supremacy by putting the responsibility for meaningful racial integration on the backs of black schoolchildren, rather than on the school districts themselves. Even after the Court's ruling in Green, school districts continued to implement strategies to place the intolerable burden of effectuating the Court's mandate on African-American children through disproportionate transportation burdens.

Another set of policies that served to reinforce the racial hierarchy long after the Court issued its desegregation mandate were the surreptitious strategies used by intransigent Southern school districts to purge AfricanAmerican educators from public schools. In her survey of the effect of desegregation on African-American teachers in the South, educator Mary Hatwood Futrell identified a number of recurring practices. These practices included (1) firing African-American teachers for exercising their political rights or for joining the NAACP; (2) administering reprisals to those AfricanAmerican teachers who spoke out in favor of complying with desegregative orders; (3) firing thousands of African-American teachers before districts actually desegregated; (4) abolishing tenure laws where there were large numbers of black educators, thus giving administrators the right to fire teachers without cause; (5) dismissing teachers even with tenure laws in place by hiring them outside of their certified field and then firing them for incompetence; and (6) retaining white faculty while demoting or dismissing black faculty. ${ }^{159}$ According to one report, by 1972, more than 41,600 AfricanAmerican educators in the southern states had been displaced or lost their

157. See, e.g., Mary Hatwood Futrell, The Impact of the Brown Decision on African American Educators, in THE Unfinished AgENDA of BROWN V. BOARD OF EDUCATION 79, 86-87 (Editors of BLACK IsSUES IN Higher EdUC. et al. eds., 2004).

158. Green v. County Sch. Bd., 391 U.S. 430, 490 (1968).

159. Futrell, supra note 157, at 86-87. 
jobs. ${ }^{160}$ More than half of all black public school administrators were demoted or dismissed. ${ }^{161}$ Moreover, those black teachers who did desegregate previously all-white schools usually found themselves in hostile environments where some white teachers refused to even speak to them or questioned the validity of their teaching credentials. ${ }^{162}$ In addition, little professional development training was provided to help acculturate black and white students or teachers into the newly desegregated schools. ${ }^{163}$

Policies that sadly were hallmarks of the post-Brown era, such as closing previously all-black schools, placing disproportionate transportation burdens on black children, and purging African-American teachers from schools, were fundamentally designed to accommodate white students and teachers. The long-term stigmatizing effects of these policies were highlighted by at least one federal district court in the South years later. In one long-standing school desegregation case, ${ }^{164}$ a federal district court judge in South Carolina noted that closing African-American institutions would have the potential to further the racial stigmatization that thrived under a system of state-sponsored segregation. In that case, the court required the implementation of a magnet program at a historically black high school, rather than closing the high school altogether:

The District stigmatized [the high school] as an inferior black school. If the "nature of the violation" was the District's discrimination against [the school], then the remedy cannot be one that rewards the District by closing the school. To allow the District to close the last remaining historically black secondary school in the county would be to consummate, not remedy, the stigma and injury inflicted upon "the race disfavored by the violation." 165

Despite the Brown Court's intentions to provide black students with increased opportunities, at least in the short run, the decision had the deleterious effect of decimating a cadre of powerful academic role models for black and white students. This helped to reinforce, rather than eradicate, the disequilibrium wrought by the deeply entrenched American racial hierarchy.

160. Id. at 89 (citing Samuel B. Ethridge, Impact of the 1954 Brown v. Topeka Board of Education Decision on Black Educators, 4 Negro EdUC. ReV. 30 (1979)).

161. $I d$.

162. Id. at 88 .

163. $I d$.

164. Stanley v. Darlington County Sch. Dist., 879 F. Supp. 1341 (D.S.C. 1995).

165. Id. at 1388 (quoting Freeman v. Pitts, 503 U.S. 467, 485 (1992)); see also Lee v. Autauga County Bd. of Educ., 59 F. Supp. 2d 1199 (M.D. Ala. 1999). 
These remedies, purported to rectify the violation of constitutional rights identified in Brown, were grounded in an idealistic assumption that a focus on racial balancing in schools was sufficient without a corresponding frontal attack on the deep-rooted notions of racial hierarchy inherent in our society. In failing to order more holistic remedial measures, the courts allowed racial prejudices that affected the hearts and minds of both black and white students to persist. This made it exceedingly difficult for educators, policymakers, and practitioners to have an honest dialogue about the harmful effects of the deeply entrenched racial hegemony that persisted in schools long after the legal structure of apartheid ended. In the absence of a frank discussion of the need for a panoply of race-based reforms to address the harmful social and psychological effects of racial segregation, the very language of racial stigma has been co-opted by those who have sought an end to the precise remedies aimed at eradicating the deleterious vestiges of state-sponsored racial segregation and discrimination. ${ }^{166}$

Ultimately, as Justice Marshall opined in his Milliken dissent, desegregation is not and was never expected to be an easy task. ${ }^{167}$ The failures in the full implementation of Brown's mandate point to the idealism of the lawyers who hoped that the long-arm of the Constitution, through the Court's directive, would unalterably push the nation toward fundamental racial reform and increased educational opportunities. True racial integration, unfortunately, entails more than the simple dismantling of the legal structures that forced the separation of races. The failure to achieve this genuine integration stems in part from the failure of courts to provide remedies for constitutional violations, because they perceived such remedies as too difficult to implement. Later, courts missed opportunities to address the vestiges of segregation by treating intersecting issues, such as the relationship between persistent residential segregation and the continued racial segregation in public schools, as non-justiciable. ${ }^{168}$ The end result is that a half-century after

166. In the voting rights contexts, see, e.g., Miller v. Johnson, 515 U.S. 900, 909-11 (1995); United States v. Hays, 515 U.S. 737, 746-47 (1995) (citing appellees' complaint that Louisiana's redistricting scheme violated white voters' right to engage in a color-blind process); Shaw v. Reno, 509 U.S. 630, 641-43 (1993) (pointing to language in appellants' complaint that North Carolina's redistricting scheme deprived white voters of the right to participate in a color-blind election process).

167. Milliken v. Bradley, 418 U.S. 717, 814 (1974) (Marshall, J., dissenting).

168. See, e.g., Missouri v. Jenkins, 515 U.S. 70, 120 (1995) (Thomas, J., concurring) (“[N]eutral policies, such as local school assignments, do not offend the Constitution when individual private choices concerning work or residence produce schools with high black populations."). This is a departure from the Court's holding in 1971 that planned segregation of schools led to segregated housing. Swann v. CharlotteMecklenburg Bd. of Educ., 402 U.S. 1, 21 (1971). See also Denton, supra note 77, at 801-06. 
Brown, we are still seeking some of the broad racial reforms that would effectuate Brown's mandate.

\section{Voluntary School Desegregation Plans and the Future of RACIAL INCLUSION}

In Brown, the Court reminded us that "education is perhaps the most important function of state and local governments," in part because "[i]t is required in the performance of our most basic public responsibilities." ${ }^{169}$ The matter of school desegregation is really a microcosm of race relations in broader society. For, as the Court acknowledged:

It is the very foundation of good citizenship. . . . [I]t is a principal instrument in awakening the child to cultural values, in preparing him for later professional training, and in helping him to adjust normally to his environment. ... [I]t is doubtful that any child may reasonably be expected to succeed in life if he is denied the opportunity of an education. ${ }^{170}$

Schools are the places where children learn the values and skills that will take them through the rest of their lives. It makes sense then that schools should be the laboratories for the expurgation of the evils of segregation and racism and for the embracing of racial tolerance. For those who believe in the continued relevance of litigation as one of many tools for genuine social change, and for those interested in creating and maintaining integrated schools, some of the most promising avenues for success looking forward may lie in the Supreme Court's most recent decision regarding race-conscious policies in higher education, as well as in the opinions of lower courts upholding voluntary integrative measures to create and maintain access to equal educational opportunity.

While efforts to eliminate the legal structure of racial segregation and the racial caste system that support it have fallen short, it is apparent that the ideals put forth in Brown, when implemented by conscientious courts and school districts, have yielded significant benefits for all students involved. Efforts to end the practices that accompany racial segregation, including inferior educational resources in terms of school facilities, books, technology, and teachers, and to end the racial stigmatization of minority students that facilitates the continued exclusion of minorities from mainstream society and

169. Brown v. Bd. of Educ., 347 U.S. 483, 493 (1954).

170. $I d$. 
opportunity structures, can best be accomplished by focusing both on improving measures for true integration and providing students with the necessary resources to obtain the best educational opportunities possible.

The critical challenge of the twenty-first century is to maximize the successes of previous school desegregation litigation, without recreating or perpetuating the flaws of the traditional one-dimensional integration strategy and remedy. There are ways to trumpet the integrative ideal in public education while also utilizing critical structures that emphasize equalization and holistic remedies. Addressing such issues requires broad, complex solutions, many, if not most, of which may not seem politically feasible. Yet, even within existing institutional and political structures, there are certain programs that make some strides toward increasing integration while addressing some of the necessary structural remedies.

\section{A. True Integration and Equality in Voluntary Race-Conscious Programs}

In this vein, there are a number of school districts that have voluntarily adopted race-conscious programs to try to correct the flaws in the traditional desegregative strategy and in the one-dimensional remedy instituted in the wake of Brown. As recent court rulings have lessened the scope of courtordered desegregative remedies, ${ }^{171}$ voluntarily instituted policies and practices provide avenues to address racial isolation and concentrations of poverty. ${ }^{172}$ They combine true integrative policies with a corresponding focus on resources. These policies have also been informed by the compelling interest in remedying de facto educational and residential segregation. ${ }^{173}$

One useful example of such a policy is the voluntary desegregation program adopted by the school district in the multiracial town of Lynn, Massachusetts. ${ }^{174}$ The program uses holistic integrative measures with a

171. See Jenkins, 515 U.S. 70; Freeman v. Pitts, 503 U.S. 467 (1992); Bd. of Educ. v. Dowell, 498 U.S. 237 (1991).

172. The Court's ruling in Milliken has made it very difficult to address urban-suburban segregation absent a showing of an inter-district violation and, as such, some of the best hope for constitutional jurisprudence to support integrative measures resides in the intra-district remedies that school districts have voluntarily implemented.

173. Brewer v. W. Irondequoit Cent. Sch. Dist., 212 F.3d 738, 752 (2d Cir. 2000) (holding "that a compelling interest can be found in a program that has as its object the reduction of racial isolation and what appears to be de facto segregation"); see also Comfort v. Lynn Sch. Comm., 263 F. Supp. 2d 209, 264, 266 (D. Mass. 2003), amended by 283 F. Supp. 2 d 328 (D. Mass. 2003), and aff'd en banc, 418 F.2d 1 (1st Cir. 2005) (holding that a school district had a compelling interest in ameliorating the effects of de facto residential segregation).

174. See Comfort, 263 F. Supp. $2 \mathrm{~d}$ at 213, 215. 
corresponding focus on expenditures in a way that has not been done in many traditional desegregation plans. The program looks at equity and desegregation, while also looking to the quality of desegregation. As discussed earlier, Professor Bell has cautioned that the desegregation process is successful only when it does not ultimately disrupt the dominant racial power structure. ${ }^{175}$ But the race-conscious program voluntarily adopted by the Lynn district actually attempts to alter the racial hierarchy, because it looks to racial balancing as well as the quality of interaction between students of different races. Such attention to detail in schools and classrooms addresses a deficiency in most previous desegregation plans.

The Lynn school district's student assignment plan carefully includes holistic measures to address the issue of racial tolerance. The plan's drafters "recognized that integration involves more than race-conscious school assignment policies, more than simply the mixing of students of different racial backgrounds." ${ }^{176}$ In voluntarily addressing the flawed remedial patterns of Brown that reinforced racial stigma, the plan includes a number of holistic integrative measures, including

substantial curricular innovations designed to ensure positive racial interaction; training and development of staff to address the challenges of teaching children of diverse backgrounds; programs that would create opportunities for positive interaction among students, school personnel and parents from different racial and ethnic groups ...; [and] integrated leadership opportunities and training to give students the skills necessary to deal effectively with racial tension and conflict .... ${ }^{177}$

Moreover, the plan combines these integrative remedies with expenditures to improve physical facilities and to develop and standardize curricular offerings. ${ }^{178}$ Such models may prove the most effective tools for achieving true integration, and may also elicit less criticism because they combine the consideration of race with many other equally essential factors leading to increased educational opportunities for all children. Moreover, the Lynn, Massachusetts plan explicitly addresses the ideal of integration and the necessity for the provision of adequate institutional resources in the face of entrenched, systemic racial inequities. ${ }^{179}$

175. Bell, Covenants, supra note 105 , at $49-58$.

176. Comfort, 263 F. Supp. $2 d$ at 229.

177. Id.

178. Id.

179. Id. at 229-30. 
In recent years, parents of white students have challenged some voluntary race-conscious policies on the ground that they violate the Equal Protection Clause of the Fourteenth Amendment. The central question in these cases is whether the voluntary use of race to assign or admit students to public school satisfies a compelling state interest. ${ }^{180}$ Parents of elementary school children in Lynn challenged the school district's voluntary use of race in permitting student transfers. The Plan withstood constitutional challenge at the district court and appellate levels. ${ }^{181}$

Significantly, the Supreme Court has yet to rule on the use of race in a voluntary integration policy at the elementary or secondary level. Yet, several recent lower court rulings have sustained such policies in the face of constitutional attacks. ${ }^{182}$ Given the Supreme Court's recent jurisprudence upholding the constitutionality of race-conscious policies in higher education, such voluntary school desegregation plans at the elementary and secondary level may provide the positive models for taking the Court's ruling in Brown a step closer to achieving equality of educational opportunity. ${ }^{183}$ As two lower courts have recently reached different conclusions in evaluating the constitutionality of voluntary race-conscious plans at the K-12 level in the wake of Grutter, this issue will likely reach the Supreme Court in the future. I argue that Grutter provides a positive tool for upholding race-conscious policies at the K-12 level, because it is arguably the best and most important place to seek racial inclusion.

180. See, e.g., Tuttle v. Arlington County Sch. Bd., 195 F.3d 698 (4th Cir. 1999); Wessman v. Gittens, 160 F.3d 790 (1st Cir. 1998).

181. The case is currently on appeal.

182. See, e.g., Brewer, 212 F.3d 738; Hunter v. Regents of the Univ. of Cal., 190 F.3d 1061 (9th Cir. 1999); McFarland v. Jefferson County Pub. Sch., 330 F. Supp. 2 d 834 (W.D. Ky. 2004); Comfort, 263 F. Supp. 2d 209.

183. Though beyond the scope of this paper, the impact of ballot initiatives like Proposition 209 in California and Initiative 200 in Washington State, which both ban racial discrimination and "preferential treatment" in the operation of public education, adds an interesting level of complexity to the role of voluntary race-conscious programs in public education. Proposition 209 (amending CAL. ConsT. art. I, $\S 31$ (1996)); Initiative 200 (amending Wash. Rev. Code $\S 49.60 .400$ (1998)). Yet, in Washington, the state supreme court upheld the use of such policies on the grounds that they did not constitute a racial preference. Parents Involved in Cmty. Sch. v. Seattle Sch. Dist. No. 1, 72 P.3d 151 (Wash. 2003). The court held that such policies (1) did not promote a less qualified minority applicant over a more qualified applicant; (2) applied equally to members of all races; and (3) furthered a core mission of public education. Id. at 166. For further discussion of Seattle's race-conscious program, see infra Part IV.B.3. 


\section{B. Supporting Voluntary Desegregation Plans Under Grutter}

In June 2003, the Supreme Court may have issued its most revolutionary statement on race and the importance of racial inclusion in the last thirty years. In Grutter v. Bollinger, a white plaintiff challenged the use of race as one of many factors in determining admissions to the University of Michigan Law School. ${ }^{184}$ Using a strict scrutiny analysis, the Court upheld the use of race as a factor in furtherance of the compelling government interest of increasing student body diversity, and held that the Law School's admissions policy was sufficiently narrowly tailored to further that interest. ${ }^{185}$ While this case specifically addressed the use of race in affirmative action policies in institutions of higher education, it may also help school districts defend raceconscious practices aimed at fostering diverse student bodies at the elementary and secondary levels. Grutter is a positive sign in what has been a negative landscape. Therefore, advocates should capitalize on the Court's willingness to consider race in the educational setting.

First, the Court quoted directly from the Brown ruling in reaching its decision that "education ... is the very foundation of good citizenship." 186 In this way, Grutter represents a vehicle to use integrative policies to create and maintain access to equal educational opportunity at all levels. As in Brown, the Court in Grutter also recognized that education has the important social purpose of helping people function effectively in a democratic society. ${ }^{187}$

Second, the Court acknowledged the continued salience of race in our society and the need for policies to address inequalities. The Court acknowledged arguments regarding the continuing struggle for racial

184. Grutter v. Bollinger, 539 U.S. 306, 316-17 (2003).

185. Id. at 343-44. In the companion case, the Supreme Court struck down the admissions policy of the University of Michigan's College of Literature, Science, and the Arts on narrow tailoring grounds. Gratz v. Bollinger, 539 U.S. 244 (2003).

186. Grutter, 539 U.S. at 331 (quoting Brown v. Bd. of Educ., 347 U.S. 483, 493 (1954)). The Court referenced the spirit of Brown in emphasizing that "[e]ffective participation by members of all racial and ethnic groups in the civic life of our Nation is essential if the dream of one Nation, indivisible, is to be realized." Id. at 332 .

187. Just as the Court fifty years ago acknowledged that a sound education is required in the performance of all basic public responsibilities, including the armed forces, Brown, 347 U.S. at 493, the Court in Grutter noted the necessity of successful integration for the American economic system and for national security. Grutter, 539 U.S. at 330-31. ("[M]ajor American businesses have made clear that the skills needed in today's increasingly global marketplace can only be developed through exposure to widely diverse people, cultures, ideas, and viewpoints. . . To fulfill its mission, the military 'must ... train and educate a highly qualified, racially diverse officer corps in a racially diverse setting.'”). 
equality. ${ }^{188}$ In addressing the continued need for race-conscious policies, the Court helped to reverse the trend that assumes a moral equivalence between the legacy of racial segregation and the use of race today to dismantle that legacy. ${ }^{189}$

Looking forward, the realm of school desegregation jurisprudence may be further shaped by courts' applications of a Grutter analysis to determine the constitutionality of voluntary race-conscious programs in public education that are increasingly under attack. ${ }^{190}$ The Court's decision in Grutter gives a boost to advocates for the preservation of integrative remedies as a means for increasing educational opportunities at all levels.

\section{The Concept of Critical Mass}

In Grutter, the Court decried the practice of racial balancing "for its own sake," stating that such a practice would be "patently unconstitutional."."191 The Court cited its 1992 opinion in Pitts, which addressed the factors to be considered in releasing a school district from a court-ordered desegregation plan. Yet, the true origin of the Court's language on this point is instructive. The Pitts language cited in Grutter for the proposition that racial balancing for its own sake is unconstitutional was first stated in the Court's 1971 opinion

188. See, e.g., Brief for the NAACP Legal Defense and Educational Fund, Inc. and the American Civil Liberties Union as Amici Curiae in Support of Respondents, Grutter v. Bollinger, 539 U.S. 306 (2003) (No. 02-241), in 5 Rutgers Race \& L. Rev. 149 (2003). The Grutter Court recognized that there is a "unique experience of being a racial minority in a society, like our own, in which race unfortunately still matters." Grutter, 539 U.S. at 333.

189. As Professor Randall Kennedy eloquently stated:

In the forties, fifties, and early sixties, ... it seemed that racial subjugation could be overcome by mandating the application of race-blind law... The opponents of affirmative action have stripped the historical context from the demand for race-blind law. They have fashioned this demand into a new totem and insist on deference to it no matter what its effects upon the very group the fourteenth amendment was created to protect. Brown and its progeny do not stand for the abstract principle that [all] governmental distinctions based on race are unconstitutional. Rather, [they] ... stand for the proposition that the Constitution prohibits any arrangements imposing racial subjugation - whether such arrangements are ostensibly race-neutral or even ostensibly race-blind. Randall Kennedy, Persuasion and Distrust: A Comment on the Affirmative Action Debate, 99 HARv. L. REv. 1327, 1335-36 (1986) (citations omitted); see also T. Alexander Aleinikoff, A Case for RaceConsciousness, 91 Colum. L. Rev. 1060 (1991).

190. While there are a number of different types of such programs, this Section focuses on the voluntary use of traditional intra-district race-conscious programs in public schools. Although the analysis could be applied to other types of race-conscious programs, such as magnet and charter schools, I will save such a discussion for a future paper.

191. Grutter, 539 U.S. at 329-30 (citing Freeman v. Pitts, 503 U.S. 467, 494 (1992) ("Racial balance is not to be achieved for its own sake.")). 
in Swann. ${ }^{192}$ Read more fully, the language in Swann provides the Court's clearest pronouncement as to the constitutionality of voluntary race-conscious student assignment plans in the K-12 context. In Swann, the Court noted that:

School authorities are traditionally charged with broad power to formulate and implement educational policy and might well conclude, for example, that in order to prepare students to live in a pluralistic society each school should have a prescribed ratio of Negro to white students reflecting the proportion for the district as a whole. ${ }^{193}$

The Court further held that, while a federal court lacks the authority to order such a policy "absent a finding of a constitutional violation," it "is within the broad discretionary powers of school authorities" to look at race in assigning students to schools as a matter of educational policy. ${ }^{194}$ Thus, the Court's language in Swann suggests it is within a school district's broad discretion to voluntarily use racial balancing as an educational policy. Under Swann, the Court suggested that a school district may choose to adopt such a policy to "prepare students to live in a pluralistic society.","195

In Grutter, the Court reached a similar point in its discussion of the concept of garnering a "critical mass" of minority students, which it tied to the compelling state interest of the "educational benefits that diversity is designed to produce." 196 As in Grutter, voluntary race-conscious student assignment plans in elementary and secondary schools do not constitute racial balancing "for its own sake" rather, it is a school district's voluntary consideration of race in assigning students for the purposes of producing educational benefits tied to diversity. In the case of these programs, such benefits include the reasoning set forth in Swann more than 30 years ago. These programs continue to help "prepare students to live in a pluralistic society."197

192. See Pitts, 503 U.S. at 494 (citing Swann v. Charlotte-Mecklenburg Bd. of Educ., 402 U.S. 1, 31-32 (1971)).

193. Swann, 402 U.S. at 16.

194. $I d$.

195. $I d$.

196. Grutter, 539 U.S. at 330.

197. It is worth noting that the only other context of "unconstitutional" racial balancing that the Court has referenced is in its ruling in City of Richmond v. J. A. Croson Co., 488 U.S. 469 (1989). This is arguably inapposite, as the case addressed the constitutionality of affirmative action in contracting and has no relation to education. 


\section{The Compelling Interest in Racial Integration}

In Grutter, the Court used the strict scrutiny test to determine whether the use of race in a law school admissions policy furthered a compelling government interest and whether the admissions policy was sufficiently narrowly tailored to further that interest. The Court found that the use of race to further student body diversity served a compelling government interest. School districts' voluntary use of race-conscious plans also serves this compelling interest. Indeed, the context of K-12 education arguably presents an even more compelling case for racial inclusion and provides an arena in which courts have historically given great deference to the choices of local districts to effectuate educational policy.

One of the most crucial lessons to emerge from Grutter is that courts applying strict scrutiny to racial classifications must attune their inquiries to the context of the race-conscious action. ${ }^{198}$ Beyond whatever doctrinal shift in education law that Grutter may portend more broadly, the context of K-12 public education provides a particularly compelling argument for the necessity of integrative measures. As one lower court opined, "[d]iversity may well be more important at this stage than at any other-[because elementary school] is when first friendships are formed and important attitudes shaped. ..." ${ }^{199}$ At the earliest stages of education, the shadow of racism has had less time to hover. Even Justice Scalia in his Grutter dissent suggested cross-racial understanding falls under the purview of elementary education. ${ }^{200}$ Scalia's comment shows support from an unexpected place and further buttresses the argument that the most important arena in which to address issues of racial isolation is elementary and secondary education.

198. Grutter v. Bollinger, 539 U.S. 306, 327 (2003).

Context matters when reviewing race-based governmental action under the Equal Protection Clause. . . . Not every decision influenced by race is equally objectionable and strict scrutiny is designed to provide a framework for carefully examining the importance and the sincerity of the reasons advanced by the governmental decisionmaker for the use of race in that particular context. (citations omitted).

199. Boston's Children First v. City of Boston, 62 F. Supp. 2d 247, 259 (D. Mass. 1999).

200. In his dissent, Scalia noted that " $[\mathrm{t}]$ he educational benefit ... of cross-racial understanding and better prep[aration of] students for an increasingly diverse workforce and society [is] . . essentially the same lesson taught to ... people three feet shorter and twenty years younger than the full-grown adults at the University of Michigan Law School, in institutions ranging from Boy Scout troops to public-school kindergartens." Grutter, 539 U.S. at 347 (Scalia, J., dissenting) (citations and quotations omitted). 
Public elementary and secondary schools have the unique role of imparting civic values to students at a critical age. In a number of public education cases, the Supreme Court has noted that the fundamental goal of elementary and secondary education is to prepare children to be good citizens, which includes instilling civic values and developing strong social skills. ${ }^{201}$ In the realm of elementary and secondary education, courts have long noted that the benefits of integrated systems have the ability to take root with younger children, and thus may be even more critical at this stage. As Judge Waties Waring powerfully stated in his dissent in the district court decision of the South Carolina companion case to Brown:

There is absolutely no reasonable explanation for racial prejudice. It is all caused by unreasoning emotional reactions and these are gained in early childhood. Let the little child's mind be poisoned by prejudice of this kind and it is practically impossible to remove these impressions however many years he may have of teaching by philosophers, religious leaders or patriotic citizens. If segregation is wrong, then the place to stop it is in the first grade and not in graduate colleges. ${ }^{202}$

Moreover, as discussed earlier, ${ }^{203}$ we have a significant body of social science research accepted by courts ${ }^{204}$ that shows the educational benefits of racially integrated systems of education. ${ }^{205}$ Increased opportunities for cross-racial interaction at the elementary and secondary levels teach students civic values, produce strong social skills, and are pivotal to proper engagement in the democratic and political process.

In addition to a compelling interest in racial diversity at the K-12 level that is as strong or stronger than the interest expressed in Grutter, the Grutter Court also exhibited deference to educational institutions' choices in evaluating whether the use of race furthered a compelling government interest.

201. See, e.g., Bethel Sch. Dist. No. 403 v. Fraser, 478 U.S. 675, 683 (1986); Plyler v. Doe, 457 U.S. 202, 221-23 (1982) (noting that public education perpetuates the political system and the economic and social advancement of citizens); Ambach v. Norwick, 441 U.S. 68, 76-77 (1979) (observing that public schools convey to children "the values on which our society rests," including "fundamental values necessary to the maintenance of a democratic political system").

202. Briggs v. Elliott, 98 F. Supp. 529, 547 (E.D.S.C. 1951) (Waring, J., dissenting).

203. See supra Part III.B.

204. See, e.g., Comfort v. Lynn Sch. Comm., 263 F. Supp. 2d 209, 234-38. See also Grutter, 539 U.S. at 330 .

205. In a sense, this evidence that all students benefit from racial integration may represent the triumph of a part of Derrick Bell's interest-convergence theory. As discussed earlier, Bell has argued that racial progress only occurs when policymakers perceive that such action will benefit the nation's interest and will not significantly diminish whites' sense of entitlement. BELL, CovenanTs, supra note 104, at 9. The interest-convergence at work in the K-12 realm is that research shows that racial integration in schools benefits all children and, ultimately, helps to build a stronger democracy. 
Similarly, in the K-12 realm, courts have shown deference to local school districts' efforts to fashion educational policies. The basis for such deference in the K-12 model is different than in the case of university admissions, where the Court reaffirmed the notion that academic freedom rooted in the First Amendment supported some deference to the university. ${ }^{206}$ Nonetheless, the Grutter Court's explicit deference to defendants on the legal question of whether diversity serves a compelling government interest in the context of the challenged program ${ }^{207}$ suggests that the principles of local control that the Court has long held to be essential in crafting K-12 educational policy would allow for a similarly deferential strict scrutiny analysis.

In previous decisions that struck down court-ordered race-conscious remedies in education, such as Milliken ${ }^{208}$ and Pitts, ${ }^{209}$ the Supreme Court strongly sanctioned the role and significance of local elected school boards in fashioning educational policies for their communities. ${ }^{210}$ Such decisions suggest the Court should be similarly deferential to local authorities' abilities to voluntarily implement and maintain desegregative plans designed to address diversity within the borders of their particular school district. ${ }^{211}$ Recently,

206. Grutter, 539 U.S. at 329.

207. Id.

208. In Milliken, the Court struck down an inter-district remedy and allowed segregated schools to persist, based on the legal rationale that " $\mathrm{n}] \mathrm{o}$ single tradition in public education is more deeply rooted than local control over the operation of schools; local autonomy has long been thought essential both to the maintenance of community concern and support for public schools and to [the] quality of the educational process." Milliken v. Bradley, 418 U.S. 717, 741-42 (1974).

209. In Pitts, the Court noted:

As we have long observed, "local autonomy of school districts is a vital national tradition." Returning schools to the control of local authorities at the earliest practicable date is essential to restore their true accountability in our governmental system. When the school district and all state entities participating with it in operating the schools make decisions in the absence of judicial supervision, they can be held accountable to the citizenry, to the political process, and to the courts in the ordinary course.

Freeman v. Pitts, 503 U.S. 467, 490 (1992) (citation omitted); see also Bd. of Educ. v. Dowell, 498 U.S. 237, 248 (1991) ("Local control over the education of children allows citizens to participate in decisionmaking, and allows innovation so that school programs can fit local needs."); Swann v. CharlotteMecklenburg Bd. of Educ., 402 U.S. 1, 16 (1971) ("Remedial judicial authority does not put judges automatically in the shoes of school authorities whose powers are plenary. Judicial authority enters only when local authority defaults."); Brown II, 349 U.S. 294, 299 (1955) ("School authorities have the primary responsibility for elucidating, assessing, and solving these problems. ...").

210. See cases cited supra note 209; see also Washington v. Seattle Sch. Dist. No. 1, 458 U.S. 457, 481-82 (1982); Dayton Bd. of Educ. v. Brinkman, 433 U.S. 406, 410 (1977); San Antonio Indep. Sch. Dist. v. Rodriguez, 411 U.S. 1, 49-51 (1973).

211. Indeed, the Sixth Circuit remarked long ago,

[i]t is the wiser course to allow for the flexibility, imagination and creativity of local school boards in providing for equal opportunity in education for all students. . . [T] here may be a variety of 
some district courts have used local control principles in a positive manner to support districts' voluntary desegregation policies. ${ }^{212}$ As one district court noted in upholding a voluntary desegregation policy:

As many school systems escape the mandate of desegregation decrees, they face for the first time a choice of direction. It would seem rather odd that the concepts of equal protection, local control and limited deference are now only one-way streets to a particular education policy, virtually prohibiting the voluntary continuation of policies once required by law. ${ }^{213}$

There may be a more progressive model of local control emerging, embedded in the recent rulings upholding voluntary school desegregation measures in $\mathrm{K}-12$ education.

\section{Narrowly Tailored K-12 Voluntary Desegregation Plans}

The Court's narrow tailoring analysis in Grutter suggests that most voluntary race-conscious plans should survive such an analysis. ${ }^{214}$ While the contextual differences between K-12 race-conscious policies and higher education race-conscious policies are even more acute in a narrow tailoring analysis, the Court's willingness to uphold such policies at the higher education level suggests that voluntary measures should endure. Unlike colleges and universities, American K-12 public education has a tradition of compulsory assignment. ${ }^{215}$ Therefore, the relevant context at the K-12 level is compulsory student assignment plans rather than selective "merit"-driven university admissions policies. ${ }^{216}$ In the context of university admissions, a common argument of those who have sought to dismantle race-conscious admissions policies is that affirmative action policies value race over

permissible means to the goal of equal opportunity, and that room for reasonable men of good will to solve these complex community problems must be preserved.

Deal v. Cincinnati Bd. of Educ., 369 F.2d 55, 61 (6th Cir. 1966).

212. It should be noted that the policies discussed here are intra-district remedies. Such policies do not address the type of inter-district remedy that the Court found unconstitutional in Milliken in the absence of a showing of an inter-district violation.

213. McFarland v. Jefferson County Pub. Sch., 330 F. Supp. 2d 834, 851 (W.D. Ky. 2004).

214. Professor Wendy Parker notes that courts have historically provided only a cursory analysis of the narrow tailoring test in desegregation cases. Wendy Parker, Connecting the Dots: Grutter, School Desegregation, and Federalism, 45 WM. \& MARY L. REV. 1691, 1740 (2004).

215. See, e.g., Bazemore v. Friday, 478 U.S. 385, 408 (1986) (White, J., concurring).

216. See Boger, supra note 154, at 1777-80 (discussing the lack of individualized assessment in K-12 assignment policies, as opposed to the higher education context). 
"merit" 217 in the distribution of a finite number of seats at colleges and universities. In the context of traditional intra-district public student assignment plans, there is no such individualized assessment of "merit," because all students will be assigned to a school in the district and in most instances are offered equivalent alternate education at another public school within the district. In the K-12 context, unlike college and university admissions, no student will be denied the opportunity of an education in the district. Thus, in the milieu of compulsory student assignment plans, the consideration of race does not result in the denial of the benefit of public education within a school district. Courts should take this distinction into consideration when determining whether such plans are sufficiently narrowly tailored to withstand constitutional scrutiny.

In addition, with respect to a narrow tailoring analysis of K-12 voluntary race-conscious student assignment plans, school districts need wide latitude in fashioning policies to increase educational opportunity because of the persistence of residential segregation that thwarts efforts to achieve significant racial diversity absent implementation of race-conscious public assignment policies. ${ }^{218}$ As discussed earlier, the need for racial diversity is arguably even more critical at the K-12 level than at the higher education level.

In Grutter, the Court looked to a number of factors to determine whether the use of race in admissions was sufficiently narrowly tailored to serve a compelling government interest. These factors include: whether the plan allows for an individualized assessment of each student; whether the plan is sufficiently flexible; whether the plan places too heavy a burden on nonminority applicants; whether the institution has considered race-neutral alternatives; and whether the plan has any time limits. ${ }^{219}$ There are a number of areas in which the Grutter narrow tailoring analysis, as applied to K-12 voluntary desegregation plans, supports the broad majority of voluntary desegregation plans.

First, the Court in Grutter looked to whether the use of affirmative action in a higher education institution's admissions policy allowed for a sufficiently individualized assessment of each student, such that it was narrowly tailored to further the compelling state interest in pursuing racial diversity. In most

217. There is, of course, a lively current debate as to what constitutes "merit" in the educational context. See, e.g., Lani Guinier, Admissions Rituals as Political Acts: Guardians at the Gates of Our Democratic Ideals, 117 HARV. L. REv. 113 (2003).

218. See, e.g., Powell \& Spencer, supra note 139, at 343; Boger, supra note 154, at 1726-27; Denton, supra note 77.

219. Grutter v. Bollinger, 539 U.S. 306, 333-44 (2003). 
K-12 voluntary desegregation plans, race is also used as one factor in determining student assignments. Such plans may provide for an individualized assessment of each student prior to assigning him or her to a school for purposes of furthering racial diversity at one school or another. In the case of McFarland v. Jefferson County Public Schools, for example, the largest school district in Kentucky operates a "managed choice" system aimed at ending racial isolation. ${ }^{220}$ The system considers many factors other than race, including need, school size, and parental preference, before assigning students to schools. ${ }^{221}$ McFarland represents the first major federal district court case to argue the constitutionality of race-conscious assignment programs in public education since Grutter, and the plan was upheld by the district court. ${ }^{222}$ Moreover, many of the concerns that have motivated the need for individualized assessment in competitive admissions policies are simply not present in the context of non-competitive transfer policies in public elementary and secondary schools. ${ }^{223}$

Second, the Court in Grutter held that a university's admissions program must be flexible and cannot use a quota system. ${ }^{224}$ Race-conscious assignment programs in public education are flexible in that they usually provide a range for the racial diversity that the districts seek to achieve in plans. This range is analogous to the Court's definition of "critical mass" in the Grutter opinion. In that case, while there were no numbers assigned to the term "critical mass," it was agreed that minority student admissions generally fell within a particular range. The Court noted "there is of course some relationship between numbers and ... providing a reasonable environment for those students admitted. Some attention to numbers, without more, does not transform a flexible admissions system into a rigid quota." ${ }^{225}$ The Court noted that seeking a range of racial diversity is not a quota and may be sufficiently flexible to withstand strict scrutiny. ${ }^{226}$

220. 330 F. Supp. 2 d 834, $841-42$ (W.D. Ky. 2004).

221. $I d$.

222. Id. But see Parents Involved in Cmty. Sch. v. Seattle Sch. Dist. No. 1, 377 F.3d 949 (9th Cir. 2004) (striking down a voluntary race-conscious K-12 plan on narrow tailoring grounds), discussed infra.

223. See Comfort v. Lynn Sch. Comm., 418 F.3d 1, 8-9 (1st Cir. 2005) (finding no need for individualized assessment in K-12 transfer policies).

224. Grutter, 539 U.S. at 334.

225. Id. at 336 (citations and quotations omitted).

226. Id. Moreover, race-conscious assignment programs in public education provide flexibility in allowing for further review in policies such as hardship assessments. Such assessments may be provided for students who prefer to attend a school in which they would not contribute to the racial diversity but where to attend another school would provide an undue hardship on the student and family. See, e.g., Comfort, 418 F.3d at 8, 9 . 
In the context of voluntary race-conscious assignment plans at the K-12 level, a desegregative policy that allows for a range of racial diversity in a school may assign students to one school or another that is not their first choice, or their neighborhood school, because to do otherwise would not result in the critical mass of minority to majority students that the district seeks in each school. All other things being equal — after an individualized assessment may allow for an examination of any pertinent non-race factors - race may ultimately be used as the deciding factor in a school assignment decision.

The Court in Grutter also analyzed the burden that race-conscious policies may have on non-minority students. In the context of voluntary desegregation plans in public education, any potential burden placed on nonminority students is significantly less than that imposed by an admissions policy allocating a finite number of seats to students at a selective college or university. As stated earlier, all students receive an adequate education within the public school system. In the case of traditional public schools, ${ }^{227}$ the goods are fungible. ${ }^{228}$ As such, the plans place no discernible burden on nonminority students in the way that the Court held such a burden might be placed on the non-minority student in the context of an affirmative action policy in higher education admissions.

While the final considerations in the Grutter narrow tailoring analysis - consideration of race-neutral alternatives and time limits - may still apply, the full exploration of race-neutral alternatives should also be considered in the context of the compelling government interest in decreasing racial isolation in $\mathrm{K}-12$ public education and the greater deference that courts give to defendants in such a context. In the milieu of higher education, the consideration of race-neutral alternatives in admissions was arguably more necessary because of the greater burden placed on non-minority students in such instances. In the context of race-conscious assignment policies in public education, no student is being denied the benefit of an education in the school district. Consequently, the consideration of race-neutral alternatives need not be as exhaustive as in the higher education admissions context.

In the wake of the Grutter decision, the Western District of Kentucky was the first district court to examine the constitutionality of voluntary integration plans in K-12 schools based on the framework provided in Grutter. In the case of McFarland, the Western District of Kentucky upheld a school

227. This is a different context than the Boston Latin School at issue in Wessmann v. Gittens, 160 F.3d 790 (1st Cir. 1998), which all parties conceded provided a distinctly different educational experience than the other public schools in the district.

228. See, e.g., Comfort, 418 F.3d 1. 
district's voluntary consideration of race in making student assignments to achieve racial integration in its schools. ${ }^{22}$ The court accepted the Board's arguments that the plan served the compelling interest of improving the educational experiences of its students, that integration had produced educational benefits for students of all races over the past twenty-five years, and that it had helped to overcome the adverse effects of concentrations of poverty that disproportionately impacted African-American students. ${ }^{230}$ The Court held that the policy was also sufficiently narrowly tailored to achieve this goal. ${ }^{231}$

Yet, appellate courts have been split in their interpretation of voluntary school desegregation plans in the wake of Grutter. In a recent en banc ruling, the First Circuit upheld the Lynn, Massachusetts voluntary desegregation plan. Utilizing the Grutter framework, the court found that Lynn had a "compelling interest in securing the educational benefits of diversity," and that the plan was "narrowly tailored to meet this compelling interest." "232 Yet, a recent decision by the Ninth Circuit Court of Appeals striking down a voluntary school desegregation plan provides a cautionary tale. In Parents Involved in Community Schools v. Seattle School District No. 1, a group of white parents challenged the Seattle school district's voluntary use of a racial tiebreaker in a student assignment plan. ${ }^{233}$ The court's ruling marked the first time a federal appellate court has evaluated a voluntary public school desegregation plan at the K-12 level since the Supreme Court's ruling in Grutter. In the Seattle case, the court struck down the desegregation policy under the narrow tailoring prong of the strict scrutiny test. ${ }^{234}$ It held that the district's use of a racial tiebreaker in assigning students to oversubscribed schools did not provide a sufficiently individualized review of each student. ${ }^{235}$ The Seattle case offers an instructive example of why the Grutter analytical framework should be applied to K-12 plans with an understanding of the unique context of such plans. In the case of the Seattle plan, the court's narrow tailoring analysis failed to account for the more subtle nuances of the voluntary assignment policies. Rather, the court supported its argument that racial tiebreakers in K-12 voluntary student assignment plans are unconstitutional 
quotas by drawing from jurisprudence from the merit-driven context of higher education and from voting rights and contracting decisions. ${ }^{236}$ But, as discussed above, the Grutter Court upheld a university admissions policy that arguably used race in a similar manner. ${ }^{237}$ Moreover, as Judge Graber noted in her dissent, such policies should be viewed in light of other Supreme Court jurisprudence granting public school districts authority to avoid racial segregation. $^{238}$

\section{CONCLUSION}

The limits of traditional desegregation strategies and remedies do not negate the powerful and well-documented benefits of racial integration for students of all races. Yet, historic practices that attacked segregation without a corresponding push for equality of resources led to remedies that too often addressed the symptoms of racial segregation and discrimination-racially separate student bodies - without addressing the underlying root causes. The fundamental flaws of the one-dimensional strategy and remedy helped to perpetuate some racially discriminatory practices in public education. By effectuating policies that seek both true integration, including holistic measures that facilitate cross-racial interaction, as well as a corresponding equality of resources, advocates and policymakers can build upon the successes of the past while also trying to avoid some of the failures. Through instituting voluntary race-conscious programs, school districts may design remedies that effectuate equality and racial inclusion. Such policies should be viewed even more positively in light of the Supreme Court's most recent positive pronouncement about the benefits of racial integration in education.

236. Id. at $969,980-82$.

237. See supra Part IV.B.1.

238. Seattle Sch. Dist. No. 1, 377 F.3d at 989 (Graber, J., dissenting). 